\title{
Impact of the transition on the total factor productivity in Croatia $^{* 1}$
}

\author{
Irena Raguž Krištić ${ }^{2}$ Ivo Družićc ${ }^{3}$ Josip Tica ${ }^{4}$
}

\begin{abstract}
The goal of this paper is to determine the impact of transition on the total factor productivity (TFP) in Croatia. Hypothesis of our paper is that transition had a positive impact on the growth rate of TFP and its share in the GDP growth. We employ growth accounting methodology to estimate TFP and structural break tests to estimate total number and location(s) of structural break(s) in the estimated TFP series. In order to test for the robustness of our results we combine different sets of assumptions and derive 18 different TFP series. The fundamental results of the paper imply that transition had a positive effect on the TFP growth rate, but it did not have statistically significant effect on the relative importance (share) of TFP in GDP growth rate. Structural break tests have indicated two statistically significant break locations in the TFP growth rate data. The first break in 1979 is
\end{abstract}

* Received: 16-06-2016; accepted: 09-12-2016

1 This work is supported by the Croatian Science Foundation, project number 7031. Authors declare that they have no other relevant or material financial interests that relate to the research described in this paper.

Acknowledgements: We would like to thank anonymous reviewers for their helpful comments. Also, we thank the participants at the $87^{\text {th }}$ Western Economic Association International Meeting in San Francisco, CA for helpful comments, especially Julian Neira and Dan Bogart.

2 Assistant Professor, Faculty of Economics and Business Zagreb, J. F. Kennedy Square 6, 10000 Zagreb, Croatia. Scientific affiliation: macroeconomics, economic growth, environmental economics, Croatian economy. Phone: +3851238 3144. Fax: +3851238 3333. E-mail: iraguzkristic@efzg.hr. Personal website:www.efzg.hr/iraguz (corresponding author).

${ }^{3}$ Full Professor, Faculty of Economics and Business Zagreb, J. F. Kennedy Square 6, 10000 Zagreb, Croatia. Scientific affiliation: Croatian economy, macroeconomics, structural changes, transition, economic growth. Phone: +385 1238 3142. Fax: +385 1 238 3333. E-mail: idruzic@efzg.hr.Personalwebsite:www.efzg.hr/idruzic.

${ }^{4}$ Full Professor, Faculty of Economics and Business Zagreb, J. F. Kennedy Square 6, 10000 Zagreb, Croatia. Scientific affiliation: macroeconomics, Croatian economy, urban economics, exchange rate economics. Phone: +3851238 3162. Fax: +3851238 3333. E-mail: jtica@ efzg.hr. Personal website: www.efzg.hr/jtica. 
closely connected with overall slowdown of growth, while the second break location in 1993 can be attributed to the transition reforms. Estimated locations of the structural breaks are robust over all 18 estimated TFP series. The basic conclusion from this research is that transition reforms have managed to spark the growth of the overall economy as well as TFP, but the relative importance of the TFP vis a vis other growth factors such as human or physical capital did not significantly change.

Key words: total factor productivity, transition, growth accounting, structural breaks

JEL classification: $030,047,052$

\section{Introduction}

In this paper we use inovative methodological approach in order to test for the effect of transition on the total factory productivity (TFP) share and growth rates in Croatia. According to exogenous growth theory (Solow, 1957, Swan, 1956) growth rate of technology (TFP) is the only factor that can explain positive and sustainable long run growth of the western economies in a period after industrial revolution. Therefore, investigation of the impact of various reforms (including transition) on the movement of TFP is a central question of a country's development strategy.

Traditional approach in the analysis of the TFP shares and growth rates is the growth accounting methodology (Barro, 1998; Solow, 1957) which is usually used in order to estimate TFP series and compare shares and growth rates of TFP between various exogenously chosen periods. One of the typical results of such approach is the stylized fact about deceleration of TFP growth rates in the advanced economies after 1970s (Griliches, 1988). Similar methodological approach was used in all other studies that have investigated TFP in transition countries (Kaser, 2005; Ganev, 2005a; Burda and Severgnini, 2009, and others).

Our methodological inovation is the usage of formal structural break tests (Andrew and Plomberger, 1994; Bai and Perron, 2003a) which can endogenously estimate beginings and ends of periods that have significantly different average growth rates. In other words we do not compare periods in history that are arbitrarely selected (for example pre 1990 and post 1990), which is a literature standard (Christensen et al., 1980; Jorgenson and Yip, 2001). We use structural break test in order to endogenously estimate number of periods that are statistical different in terms of average TFP growth rate and the share of TFP in the GDP growth rate. Interpreted in the context of the effect of transition on the TFP share and growth rate, our methodology will result with conclusion whether there is a statistical difference at all before and after 1990 and also before and after all other years in our sample. We do not impose the timing of transition on our data (as other authors exogenously do), we let the data to speak for themselves. 
Formally, transition from centrally planned (self-managed) economy toward market economy in Croatia started in 1990. The basic premise of transition process was the hypothesis that private ownership will lead to the more efficient usage of human and physical capital and labor. In terms of growth accounting such theoretical expectation was supposed to be reflected in a change of TFP. More efficient usage of factors of productions basically means higher output with the same amount of capital and labor, or the same level of output with lower level of employment and capacity utilization. In other words transition was designed with a goal of increasing the growth rate and the role of TFP in general. Previous studies on the TFP in the transition economies found an increase in TFP growth rates (Macours and Swinnen, 2000; Kaser, 2005, Iradian, 2007) and shares of TFP in GDP growth (Akdede, 2001; Krishna and Mitra, 1998) after (few initial years of) transition. However, none of them tested statistical significance of the differences in the TFP growth rates and shares of TFP in GDP growth in the periods before and after transition. Therefore, the goal of this paper is to econometrically analyze the effect of transition on the growth rate of TFP and on its share in GDP growth rate in Croatia.

The data used in this paper are quite unique due to the fact that fixed investment data are available for Croatia starting with 1952. Due to length of the data series, perpetual inventory method (PIM) estimates of physical capital converge after 1968 regardless of the methodology used for estimation of the initial level of capital. The data for human capital i.e. educational attainment and average income per educational attainment group are available from 1966. For that reason estimation of robust measure of TFP in Croatia is possible for the period after 1968.

The hypothesis of this paper is that transition had a significant positive effect on the growth rate of TFP and its share in the GDP growth. To test this hypothesis, we will first use standard growth accounting methodology to estimate TFP growth rate for Croatia from 1952 to 2010 (Barro, 1998). In order to test robustness of methodology both depreciation methodologies will be used: geometric and linear (Raguž, 2011). Afterwards, two structural break tests that endogenously estimate break position(s) will be used in order to estimate statistical significance of change in TFP growth rate and the share of TFP growth rate in the growth rate of GDP (Andrews and Ploberger, 1994; Bai and Perron, 2003a).

The hypothesis is researched in the remainder of the paper as follows. In Section 2 we summarize the theoretical expectations of transition process and review the existing literature; in Section 3 we outline the growth accounting methodology and the structural break tests; Section 4 discusses the data sources and provides the results of the analysis; Section 5 discusses the results; and finally Section 6 provides some summary remarks. 


\section{Literature review}

There has been much debate in the literature over what TFP in market economies actually represents. (Lipsey and Carlaw, 2004) Points of view about TFP can be grouped in three separate streams of interpretation. First group holds the view that changes in TFP measure the rate of technological change. (Krugman, 1994; Young, 1992; Young, 1995; Crafts, 1996; Barro, 1998 and others) Jorgenson and Grilliches (1967) and Hulten (2001) see TFP growth as measuring only the 'free lunches' of technological change associated with externalities and scale effects. The third group holds the view of Abramovitz (1956) that TFP represents only a "measure of our ignorance". In the analysis of transition countries, TFP growth is mostly regarded as a measure of changes in countries' efficiency. The increase of TFP growth rate in transition period is supposed to reflect financial stability, creation of institutions for modern functioning market economies, optimization of production costs, changes in type and quality of investments, tendencies to use modern technologies etc. (Campos and Coricelli, 2002) Larger share of TFP in the GDP growth rate is expected due to the fact that TFP growth is expected to be main and leading factor driving up the GDP growth rate. (Ganev, 2005b)

\subsection{Empirical evidence in transition countries}

When it comes to estimation, TFP is most often calculated using growth accounting approach due to its simplicity and internal consistency. (Ahmed and Ghani, 2007) Alternatively, when there is enough reliable data, so called growth regressions are also very popular (e.g. Benhabib and Spiegel, 1992; Iradian, 2007; Moore and Vamvakidis, 2007). However, in the case of transition countries the main disadvantage of growth regressions is the fact that it is often difficult to construct a production function with stable parameters due to peculiar developments of factors of production and the lack of sufficiently long and reliable data series. In addition, there is a potential problem of endogeneity of production factors to the estimated model i.e. the danger of simultaneous equation bias in the growth regressions. (Hulten, 2001) That is why in the case of transition economies growth accounting methodology is regarded as the most useful. (Ganev, 2005b)

The usefulness and reliability of an indicator such as TFP derived by growth accounting is however still highly dependent upon the quality and reliability of the data. Unfortunately all transition economies face a common fundamental problem. Namely, communist period statistics often reflect planned targets rather than the real situation. They tend to overstate growth as well as the capital stock. (Chessa and Schouwstra, 2005) This is why various researchers tend to modify their analysis and avoid some of these mismeasurement issues. 
The measure of physical capital is the most disputed. Burda and Severgnini (2009) stress that plausible official estimates of sectoral and even aggregate capital stock are absent in transition countries which in turn enables wide divergences in the capital stock estimates and leads to wide divergences in TFP level and growth estimates. This is why numerous researchers have chosen to measure TFP (on sectoral or aggregate level) without the use of capital stock data (e.g. Burda and Severgnini, 2009, 2014; Bah and Brada, 2008; Ding and Knight, 2009 etc.). Alternative way of dealing with these measurement issues is to conduct sensitivity analysis. This type of analysis has been carried out by numerous researchers with respect to alternative initial capital stock levels (e.g. Iradian, 2007; Burda and Severgnini, 2014), physical capital shares (e.g. Iradian, 2007; Chessa and Schouwstra, 2005), assumed service lives of fixed assets (Wong and Seng, 1997), data sources (Moore and Vamvakidis, 2007), human capital measures (Ding and Knight, 2009; de Vries et al., 2012), geometric versus linear perpetual inventory method (Ganev, 2005b), primal versus dual growth accounting approach (Islam and Dai, 2009), etc.

As it was previously mentioned, TFP is mostly used on the macroeconomic level as an indicator of changes in countries efficiency. In many transition economies TFP is seen to have been negative in the last decade of the planned economy and starts increasing and becomes positive after a (quite a) few years of transition. (Kaser, 2005) Iradian (2007) states that during the initial years of transition, the disorganization or chaos caused by the removal of central control produces negative TFP growth rates as output falls, and a large part of the capital stock lays idle. Subsequently, as economies achieve macroeconomic stability and introduce structural reforms, the reallocation of resources to more productive activities allows the economies to generate growth with low rates of investment so that TFP growth rates increase. According to Macours and Swinnen (2000) this rebound of TFP growth rates after on average three years of transition is mostly pronounced in the observed southeast european countries (Albania, Bulgaria, Romania, Slovenia). Findings of higher TFP growth rates which accompany periods of increased economic liberalization, macroeconomic stabilization and democratization are quite robust across researches and countries. Burda and Severgnini (2009) find that from 1994 to 2000 the economies of what they call "New Europe" exhibit higher levels of TFP growth than the "New Europe" countries and that those TFP growth rates in "New Europe" were higher in the first part of the sample, few years after economic transition. Ganev (2005a) analyses different time periods for each transition and although individual trends of TFP growth rates vary, on average his results display an increase of TFP growth rates following the economic transition, mostly in 1993 and 1994. Iradian (2007) analyzes sources of growth in 27 transition economies including Croatia and finds strong correlation between the successful macroeconomic stabilization and market reforms and TFP growth in the late nineties. Akdede (2001) concluded that a period after economic liberalization 
(which was characterized not only by trade but also financial liberalization, privatization policies, democratization etc.) in the 1980s Turkey shows higher TFP growth rates, and also higher ratio of TFP growth to growth of value added. The same was also noted by Krishna and Mitra (1998) in the case of India. Hall and Jones (1999) attribute these reported high TFP levels to better institutions and Frankel and Romer (1999) stress the role of openness to trade as the driver of TFP.

Contrary to the robustness of various research results on the influence of transition on TFP growth rates, findings on the main contributors to economic growth in transition countries differ across researches and countries in question. Bah and Brada (2008) show that only in Estonia and Hungary TFP growth contributes to GDP (per capita) growth more than $50 \%$, while in other observed transition countries, physical capital seems to be the main contributor. Iradian (2007) also finds physical capital on average dominant in explaining growth in 27 transition economies, with TFP growth being dominant mostly in CIS countries. Ganev (2005a) on the other hand finds TFP as the major driving force behind GDP growth in Czech Republic, Hungary, Poland, Slovenia, Slovakia, Bulgaria and Romania.

\subsection{Empirical evidence in Croatia}

In the case of Croatia, transition began with a breakaway from Yugoslavia in 1990. At the beginning of the transition process, Croatia had less distorting institutions and incentives than other planned economies. (Roaf, 2014) This was due to the so called "self-managing" version of socialism that enabled resource allocation closer to market pricing criteria and more liberal exposure to the international market. Unfortunately, all main economic indicators were negatively impacted by the political instability and other circumstances surrounding the post-disintegration period. In such an environment, despite of its relatively favorable starting conditions, Croatia followed the mainstream transition track with certain variations. (Družić, 2006) Transition slump combined with homeland war resulted in 36\% drop in GDP between 1990 and 1993 and 21\% drop in employment during the same period. Jobless growth started after stabilization in 1993 and continued throughout the decade with real GDP increasing 32\% and employment decreasing 4\% from 1990 to 2000. Employment growth caught up only in 2000, two years after the reintegration of occupied territories. In 2008, at the beginning of global crises, GDP was $20 \%$ higher and employment $10 \%$ lower compared to 1990 (Figure 2).

Growth accounting estimates for Croatia vary across researchers. Iradian (2007) and Moore and Vamvakidis (2007) estimated dominant role for the physical capital, while Burda and Severgnini (2009) find TFP as the most dominant growth factor. When it comes to the labor contribution to growth rate, all studies indicate that share of raw labor is much smaller compared to other factors and sometimes 
even negative. The major problem with these studies is a short data sample that makes estimates of physical capital sensitive to the choice of the methodology for estimation of the initial level of capital. (Iradian, 2007, Burda and Severgnini, 2009) Also, the fact that both studies do not correct labor data for quality, the effect of the growth of human capital will, due to methodological design, end up in the Solow residual.

\section{Methodology and methods of analysis}

In order to estimate effect of transition on TFP we use two different methodologies: (i) growth accounting in tradition of Barro (1998) in order to partition growth rate of GDP into components associated with factor accumulation and technology; and (ii) econometric analysis which tests estimated TFP data and TFP share for potential structural breaks at the begining of transition.

\subsection{Growth accounting}

Growth accounting analysis starts with neoclassical production function

$$
Y=f(A, K, L)
$$

where $A$ is the level of technology, $K$ is the capital stock and $L$ is the quantity of labor. As is well known, the growth rate of output can be partitioned into components associated with factor accumulation and technological progress. In order to get the growth rate of output it is first required to differentiate equation 1 to time and divide it with income $Y$ :

$$
\frac{\dot{Y}}{Y}=\frac{f_{A}}{Y} \dot{A}+\frac{f_{K}}{Y} \dot{K}+\frac{f_{L}}{Y} \dot{L}
$$

Expressed in terms of growth rates of growth factors and technology it yields to:

$$
\frac{\dot{Y}}{Y}=\frac{f_{A} A}{Y} \frac{\dot{A}}{A}+\frac{f_{K} K}{Y} \frac{\dot{K}}{K}+\frac{f_{L} L}{Y} \frac{\dot{L}}{L}
$$

If we assume Hicks neutral technology in production function $Y=f A_{\text {hicks }}(K, L)$ and that factors are paid their marginal products $\left(f_{K}=R\right.$ and $f_{L}=W$, where $R$ is real (gross) interest rate and $W$ is real wage), then the growth rate of technology can follow from the following equation:

$$
\frac{\dot{A}}{A}=\frac{\dot{Y}}{Y}-\frac{R K}{Y} \frac{\dot{K}}{K}-\frac{W L}{Y} \frac{\dot{L}}{L}
$$


where $R K / Y$ and $W L / Y$ are the respective shares of each factor payment in total product, or - according to national accounts - share of gross operated surplus $R K / Y$ and compensation of employees $W L / Y$ in GDP. Assuming that phisical capital and labor are the only production factors that contribute to production, the sum of their income shares in GDP must equal 1, i.e. $R K / Y+W L / Y=1$ must hold. Therefore, if we assume $\alpha=R K / Y$, equation 7 yields to:

$$
\frac{\dot{A}}{A}=\frac{\dot{Y}}{Y}-\alpha \frac{\dot{K}}{K}-(1-\alpha) \frac{\dot{L}}{L}
$$

We also analyze the case with multiple qualities of labor in a production function of the following type:

$$
Y=f(A, K, L, h)
$$

where $\mathrm{h}$ represents human capital per worker. Unfortunately due to lack of data on human capital factor share of GDP we were not able to estimate Solow residual in a way suggested by Barro $(1998)^{5}$ :

$$
\frac{\dot{A}}{A}=\frac{\dot{Y}}{Y}-\frac{R K}{Y} \frac{\dot{K}}{K}-\frac{W L_{1}}{Y} \frac{\dot{L}_{1}}{L_{1}}-\frac{W L_{2}}{Y} \frac{\dot{L}_{2}}{L_{2}}-\ldots-\frac{W L_{8}}{Y} \frac{\dot{L}_{8}}{L_{8}}
$$

Therefore, Solow residual in the presence of human capital is estimated with an aggregate of labor and human capital $H=L h$.

$$
\frac{\dot{A}}{A}=\frac{\dot{Y}}{Y}-\alpha \frac{\dot{K}}{K}-(1-\alpha) \frac{\dot{H}}{H}
$$

Having in mind that only GDP data are available in official statistics or as published estimates, we have estimated physical capital and human capital using several methodologies in order to test the robustness of our TFP estimates.

In order to estimate physical capital perpetual inventory method (PIM) was used. (Harberger, 1978) In addition to Harberger's geometric depreciation of capital, we also use linear depreciation of physical capital suggested by Ganev (2005a). Geometric and linear PIM method are combined with three different initial levels of physical capital suggested by Ganev (2005a, 2005b), Easterly and Levine (2001) and Kyriacou (1991).

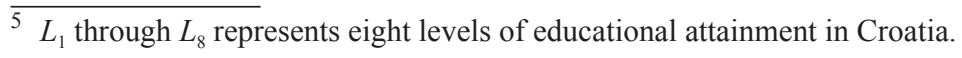


First method for initial level of physical capital is to divide real fixed investment in the first period $I_{0}(\mathrm{t}=0$ is year 1952) with depreciation rate $\delta$ (Ganev, 2005a and $2005 b):^{6}$

$$
K_{0}=\frac{I_{0}}{\delta}
$$

Alternative method is to divide product of GDP in the initial period $Y_{0}$ and average investment rate during the entire period (1952-2010) $\sum_{0}^{T} \frac{(I / Y)}{T}$ with sum of depreciation rate $\delta$ and average growth rate of GDP during the entire period $\sum_{0}^{T} \frac{\dot{Y} / Y}{T}$. (Easterly and Levine, 2001)

$$
K_{0}=\frac{Y_{0} * \sum_{0}^{T} \frac{(I / Y)}{T}}{\sum_{0}^{T} \frac{\dot{Y} / Y}{T}+\delta}
$$

The third method is to divide real fixed investment in the first period $I_{0}$ with the sum of depreciation rate $\delta$ and average growth rate of investment $\sum_{0}^{T} \frac{\dot{I} / I}{T}$. (Kyriacou, 1991)

$$
K_{0}=\frac{I_{0}}{\sum_{0}^{T} \frac{\dot{I} / I}{T}+\delta}
$$

In the rest of the text three methods for estimation of initial level of capital are marked $K 1, K 2$ and $K 3$ respectively. All three initial levels of physical capital were combined with geometric:

$$
K_{t}=(1-\delta)^{t} K_{0}+\sum_{i=0}^{t-1}(1-\delta)^{i} I_{t-i}
$$

and linear depreciation method:

$$
K_{t}=(1-t \delta) K_{0}+\sum_{i=0}^{t-1}(1-i \delta) I_{t-i}
$$

In the rest of the text estimates based on geometric depreciation are marked with suffix GEO and estimates based on linear appreciation are marked with suffix LIN.

$\overline{6}$ Depreciation rate $\delta$ is assumed to be $5 \%$ in all estimates of physical capital, which in line with most of the literature on physical capital calculations on the aggregate, macroeconomic level. (Ganev, 2005a) 
In addition to using raw labor data, we also use two different measures of human capital $H$ : $(i)$ number of employed corrected for wage differentials between workers of different educational levels $H_{1}$, and (ii) total years of schooling of labor $\mathrm{H}_{2}$. (Wößman, 2003)

The first measure of human capital is estimated as:

$$
H_{1}=\sum_{a=1}^{8} \frac{W_{a} / L_{a}}{W_{8} / L_{8}} L_{a}
$$

where $a=1 \ldots 8$ represents 8 levels of educational attaintment of labor force $(\mathrm{VSS}=1, \mathrm{VS} \breve{S}=2, \mathrm{VKV}=3, \mathrm{SSS}=4, \mathrm{NSS}=5, \mathrm{KV}=6, \mathrm{PKV}=7, \mathrm{NKV}=8), W_{a} / L_{a}$ is average wage of workers with educational attainment $a$ and $W_{8} / L_{8}$ is average wage of "row" labor with lowest (NKV) educational attaintment. ${ }^{7}$

The second measure is a sum of product of workers $L_{a}$ in each educational attainment level with the number of years required to reach a degree in each educational attainment level:

$$
H_{2}=\sum_{a=1}^{8} L_{a} * \text { years }
$$

Finally, there is a question on the estimates of factor shares in GDP that needs adressing. Namely, primary incomes in Croatian official data are divided into four categories: compensations of employees, gross operating surplus, mixed income and taxes on production and import. In order to calculate factor shares of capital we have used the share of gross operating surplus in the sum of gross operating surplus and compensations of employees. In that way we have assumed proportional tax on capital and labor, and proportional division of income from crafts, trades and free lances between labor and capital. (Barro, 1998)

\subsection{Structural breaks}

We use Andrews and Ploberger (1994) and Bai and Perron (1998; 2003a) structural break tests in order to investigate for possibility of one or more endogenously determined structural breaks in TFP shares in GDP and TFP growth rates.

Andrews and Ploberger (1994) developed asymptotically optimal test for the problem when nuisance parameter exist under alternative hypothesis but not under null. In the structural change case, the parameter that appears under alternative, but

\footnotetext{
$\overline{7}$ Jorgenson and Fraumeni (1989) used average hourly labor compensation for individuals classified by the two sexes, 61 age groups and 18 educational attainment groups. Unfortunately, due to data availability problems we had to focus on 8 educational attainment groups only.
} 
not under null is time $\pi$ of structural change as a fraction of the total sample. They consider a model:

$$
y_{t}=\delta_{t}^{\prime} x_{t}+u_{t}
$$

where $y_{t}$ is observed dependent variable at time t, $x_{t}(2 \times 1)$ is a vector of independent observed variable and $\delta_{t^{\prime}}^{\prime}(2 \times 1)$ is vector of coefficients where parametars are $\delta_{1}$ and $\delta_{2}$ before structural break and $\delta_{1}+\beta$ and $\delta_{2}$ after the structural break.

Andrews and Ploberger (1994) developed exponential LM, Wald and LR test that are asymptotically optimal in the one time structural change case in order to test hypothesis $\beta=0$ against alterantive $\beta \neq 0$.

The asymptotically optimal test statistics for exponential $\operatorname{Exp}-L M_{T}$ is defined as:

$$
\operatorname{Exp}-L M_{T}=(1+c)^{-p / 2} \int e^{\frac{1}{2(1+c)} L M_{T}(\pi)} d J(\pi)
$$

where $L M_{T}(\pi)$ is standard LM test, $c$ is scalar depending on a weight function over values of $\beta, J(\pi)$ is the weight function over values of $\pi$. One rejects $H_{0}$ if $\operatorname{Exp}-L M_{T}$ exceeds critical value $k_{T \alpha}$ that is determined using the asymptotic null distribution of $\operatorname{Exp}-L M_{T}{ }^{8}$

The biggest limitation of the Andrews and Ploberger (1994) test is the fact that it allows only for one structural break under alternative. Therefore, we proceed with Bai and Perron (2003a) test that allows more than one structural break in the model.

Bai and Perron (1998; 2003a) developed two tests that allow for multiple breaks. A sup Wald type test was designed with null hypothesis of no change versus alternative containing arbitrary $\mathrm{k}$ number of breaks and another procedure that allows the test of null hypothesis of $\ell$ changes versus alternative of $\ell+1$ changes. They consider a model:

$$
y_{t}=\beta x_{t}^{\prime}+\delta_{j} z_{t}^{\prime}+u_{t}
$$

where $j=1 \ldots m+1$ represents number of regimes, $m$ is number of breaks, $y_{t}$ is dependent variable at time $t, x_{t}(p \times 1)$ and $z_{t}(q \times 1)$ are vector covariates and $\beta$ and $\delta_{j}(j=1 \ldots m+1)$ are corresponding vectors of coefficients. $T$ is the number of observations, the indices $T_{1}, \ldots, T_{m}$ are break points and they are treated as unknowns. When $p=0$ we obtain a pure structural change model where all coefficients are subject to change:

$$
y_{t}=\delta_{j} z_{t}^{\prime}+u_{t}
$$

$\overline{8 \text { Critical values are }}$ provided by Bai and Perron (2003b). 
Bai and Perron (2003a) method is based on least-square principle. For each m-parition $\left(T_{1}, \ldots, T_{m}\right)$, the associated least-square estimates of $\delta_{j}$ are obtained minimizing:

$$
R S S_{\min }=\sum_{j=1}^{m+1} \sum_{t=T_{j-1}+1}^{T_{j}}\left[y_{t}-z_{t}^{\prime} \delta_{j}\right]^{2}
$$

We use two tests: $\sup F_{T}(k ; q)$ that tests no break versus a fixed number (k) of breaks and $\sup _{T}(\ell \mid \ell+1)$ test that sequentially tests $\ell$ breaks versus $\ell+1$ breaks. $\sup _{T}(k ; q)$ is SupF type of test defined as:

$$
F_{T}\left(\lambda_{1}, \ldots, \lambda_{k} ; q\right)=\frac{1}{T}\left(\frac{T-(k+1) q}{q k}\right) \hat{\delta}^{\prime} R^{\prime}\left(R \hat{V}(\hat{\delta}) R^{\prime}\right)^{-1} R \hat{\delta}
$$

where $k$ is number of breaks under alternative hypothesis, $\hat{V}(\hat{\delta})$ is the estimate of variance covariance matrix and $\mathrm{R}$ is conventional matrix such that $(R \delta)^{\prime}=\left(\delta_{1^{\prime}}\right.$ $\left.\delta_{2^{\prime}}, \ldots, \delta_{k^{\prime}}-\delta_{k+1}\right)$. $\sup F_{T}\left(\lambda_{1}, \ldots, \lambda_{k^{\prime}} ; q\right)$ test minimize global sum of square residuals by choosing structural change as a fraction of the total sample $\left(\hat{\lambda}_{1}, \ldots, \hat{\lambda}_{k}\right)$. This is asymptotically equivalent to maximizing the F-test. The asymptotic distribution depends on a trimming parameter via the imposition of the minimal length $h$ of segment namely $\varepsilon=h / T$.

A test of $\ell$ versus $\ell+1$ breaks labeled $\sup _{T}(\ell \mid \ell+1)$ is applied to each segment containing the observations $\hat{T}_{t-i}$ to $\hat{T}$, where $i=\ell, \ldots, \ell+1$. Null hypothesis is $\ell$ breaks and alternative, $\ell+1$ breaks. Null hypothesis is rejected if the overall minimal value of sum of squared residuals is sufficiently smaller than the sum of squared residuals from $\ell$ model. The estimate does not need to be global minimizer of the sum of squared residuals, one can also use sequential one.

\section{Data and empirical analysis}

\subsection{Data}

We use official and estimated data for GDP, employment, fixed investments, factor shares, education and wages during 1952-2010 period. For the transition period, most of the data are official series, but there are several methodological changes in coverage of GDP and employment.

GDP data during 1995-2010 are from Croatian Bureau of Statistics (CBS, 2010, 2011a). It is a real chained GDP series in constant $2000 \mathrm{kunas}^{9}$. Real GDP for 1990-

\footnotetext{
$\overline{9}$ Kuna is a local currency unit in Croatia.
} 
1994 is also official data, but it is expressed in 1990 prices (SLJH, 1997) and not with chained price index. For the period prior to 1990, official data on Croatian social product (SP) in 1972 prices was used. Consistent time series of GDP growth rates and GDP levels were then, based on these official data, estimated ("backcasted") using methodology from Družić and Tica (2002) for estimation of GDP per capita. ${ }^{10}$

Employment series is official data for paid employment in legal entities, crafts, trades and free lances, excluding private farm employment (CBS, 1999, 2001, 2011b). Due to change of methodology and inclusion of police and army personnel after 1998, we have excluded both sectors throughout the entire dataset. Data are consistent for pre and post transition period with an exception of free lancers which were officially included in employment at the begining of transition. Prior to 1990 this sector was excluded from the data, but it was much smaller. ${ }^{11}$ Figure 1 shows GDP and employment data used in analysis.

Figure 1: GDP and employment

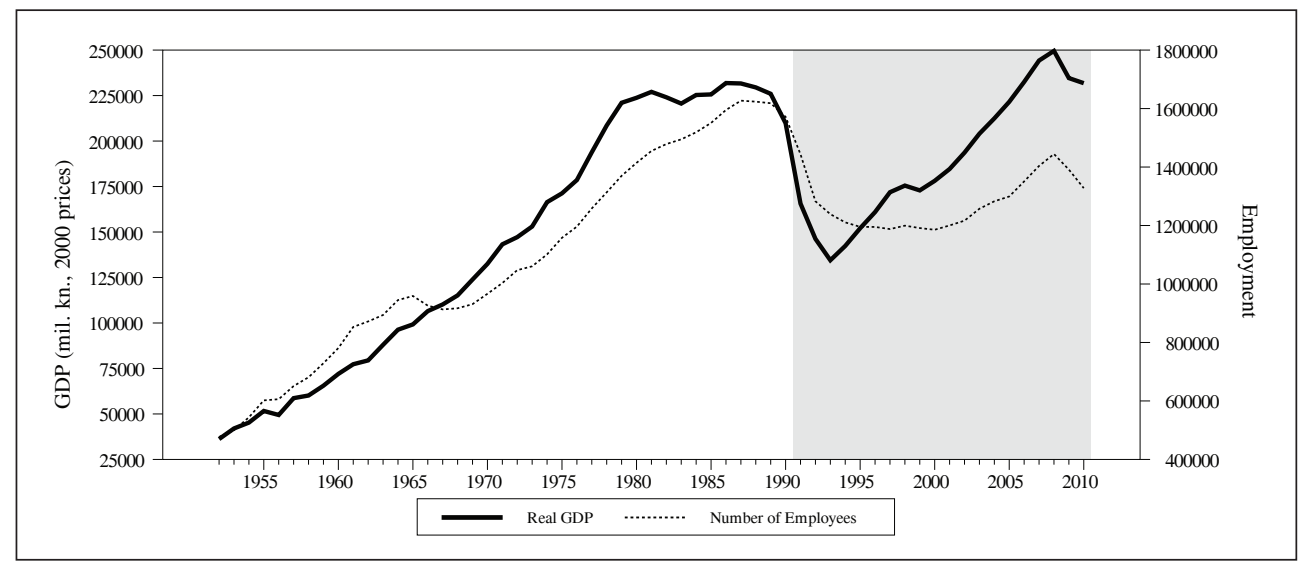

Source: CBS 1999, 2001, 2010, 2011a, 2011b, SLJH 1997

In order to estimate investment data, we have calculated the share of investment in GDP in each consecutive year. Using that approach we have avoided wide range of cumbersome issues related to the conversion of currencies and base years used in original data series (Figure 2). Prior to 1990, data for investment in basic

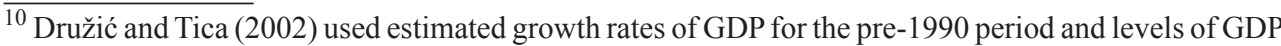
in 1990 in order to back-cast GDP levels for the pre-transition period. Estimates of the growth rates were obtained using available data on social product in Croatia and former Yugoslavia and available GDP estimates for former Yugoslavia. See Družić and Tica (2002) for additional methodological explanations.

${ }^{11}$ The number of employed in crafts, trades and free lances increased for $4.8 \%$ of total employment in 1990 , but only a fraction of this increase is due to change in methodology.
} 
funds ("osnovna sredstva") were used as a proxy for real investments (SGJ, 1982, 1989) and share of the investments in basic funds in the social product was used as a proxy for share of investments in GDP. Compared to Raguž, Družić and Tica (2011) where only investments of legal entities were used, data for basic funds include investments in the rest of the economy and data span from 1952 (compared to 1968 in previous study), which enables us to get TFP estimates less sensitive to the choice of initial physical capital level. Real investment data for the post-1990 period are from the same sources as GDP (CBS, 2010, 2011a, SLJH 1997).

Figure 2: Investment to GDP ratio update

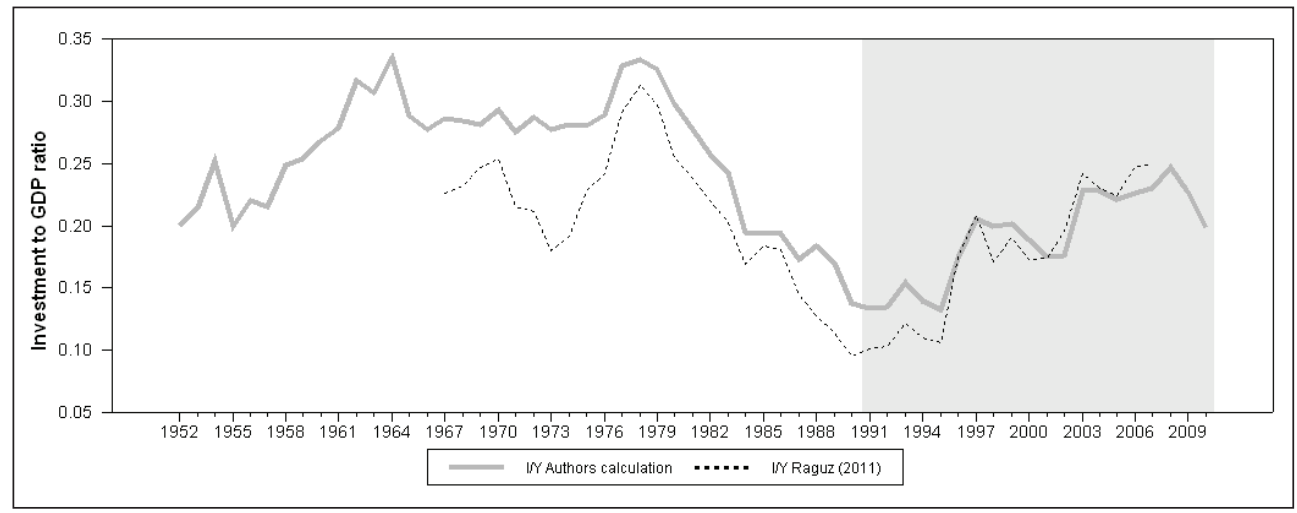

Source: CBS 2010, 2011a, SLJH 1997, SGJ 1982, 1989

Data for factor income of physical capital (gross operated surplus) are from official GDP statistics (CBS, 2009, 2010 and 2011a). Mixed income from crafts, trades and free lances is excluded from ratio as well as taxes on production and imports. For the pre 1990 period adjusted ${ }^{12}$ sum of production surplus and depreciation of capital were used as a proxy for gross operated surplus (SGH, 1971-1989). Figure 3 shows factor income data.

$\overline{12}$ Data was adjusted for the ratio between gross operated surplus share in GDP and the share of sum of production surplus and depreciation of capital in social product in 1980, 1985 and 1990. 
Figure 3: Factor share of capital

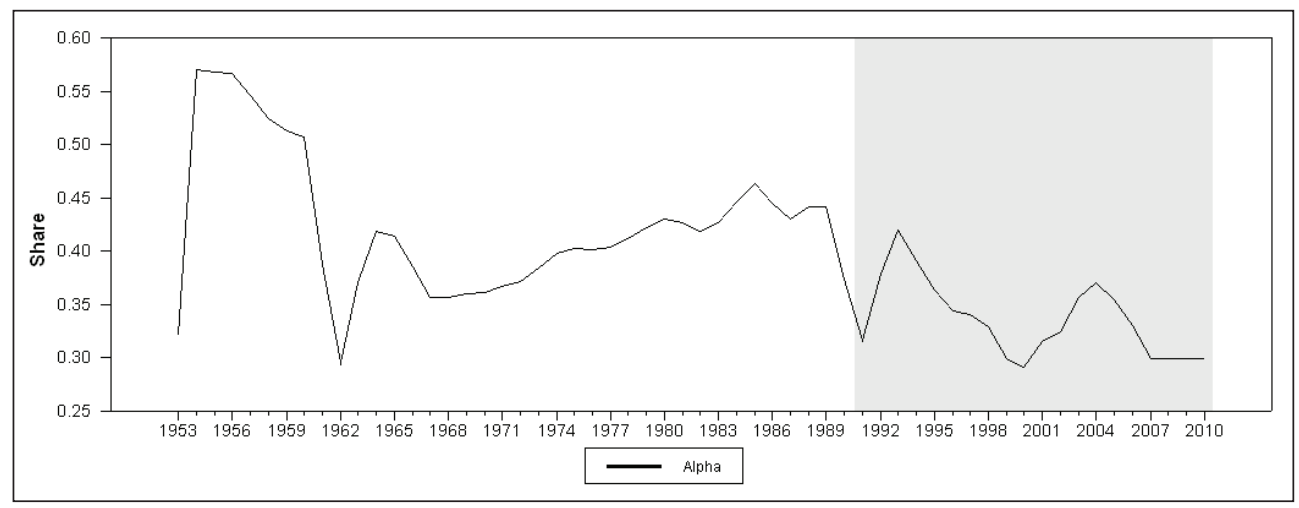

Source: SGH 1971-1989, SLJH 1991-2010, CBS 2009, 2010 and 2011a

Three different initial capital level estimates in combination with two depreciation methods have resulted with six different estimates of physical capital that are used in order to test the robustness of our methodology (Figure 4).

Figure 4: Physical capital

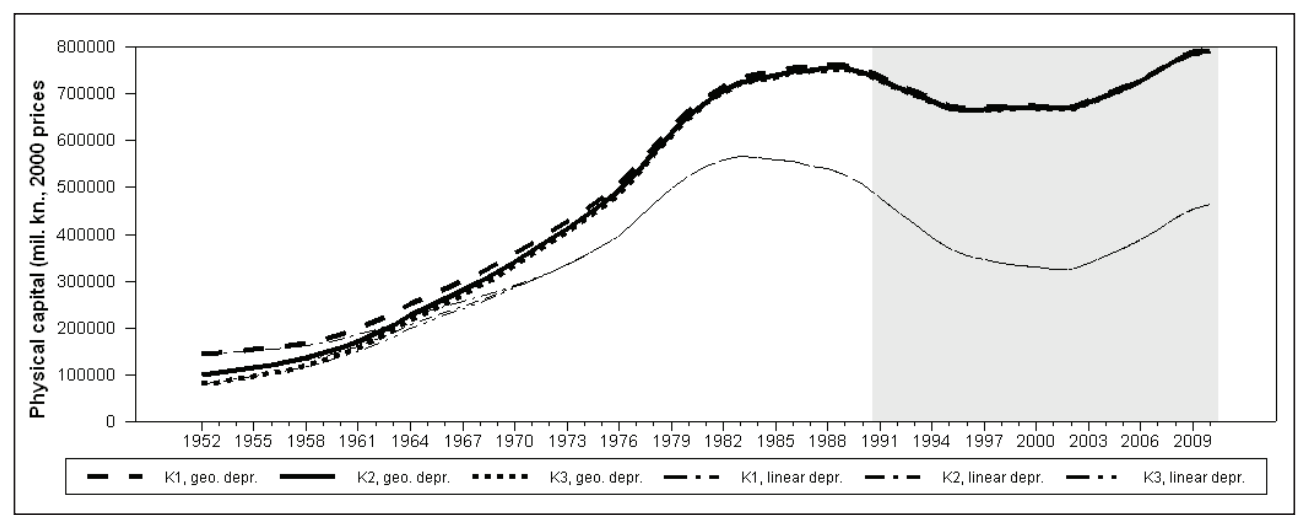

Source: Authors' calculation

In order to estimate the initial value of physical capital we used equations 9,10 and 11. In the estimation of the K3 series (Equation 11) we used growth rate of investment that was calculated using the real investment data in HRK obtained as a product of estimated real GDP (Figure 1) and share of investments in GDP (Figure 2). 
Figure 5: Employment per educational attainment

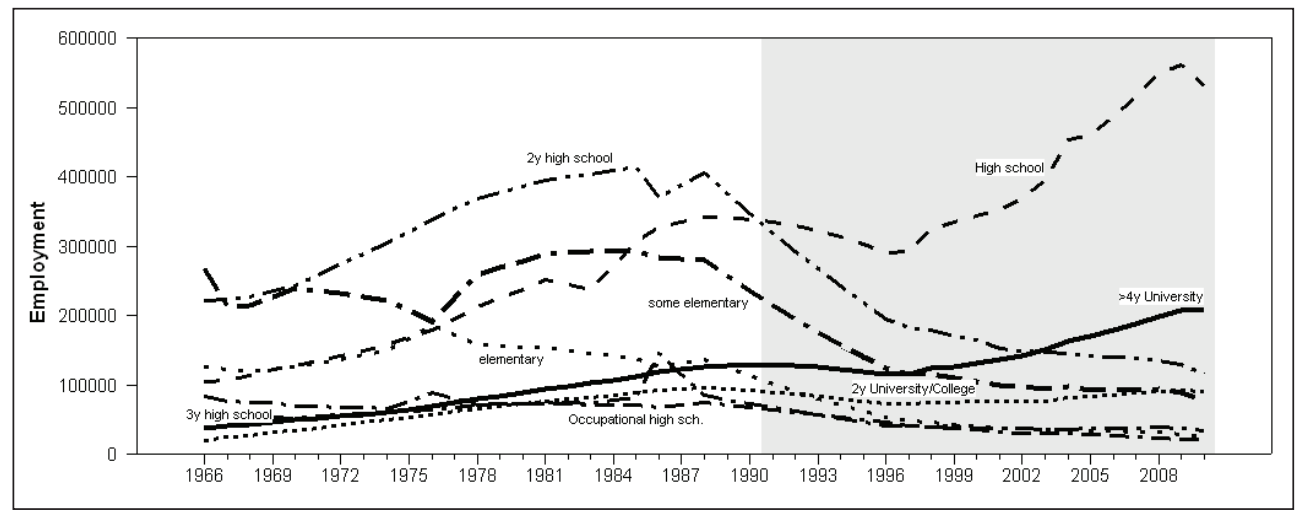

Source: SGH 1971-1989, SLJH 1991-2010, CBS 2011b

In order to estimate human capital we use data for the number of employees and average wage in each of the following 8 levels of educational attaintment of labor force during 1966-2010:

- VSS - 4 year university degree,

- VŠS - 2 or 3 year university (college) degree,

- VKV - occupational high school degree,

- SSS - general high school degree,

- NSS - 3 year highschool degree,

- KV - 2 year high school degree or non-degree,

- PKV - 8 year elementary school and

- NKV - 4 years elementary school

Figure 6: Relative wages NKV=1

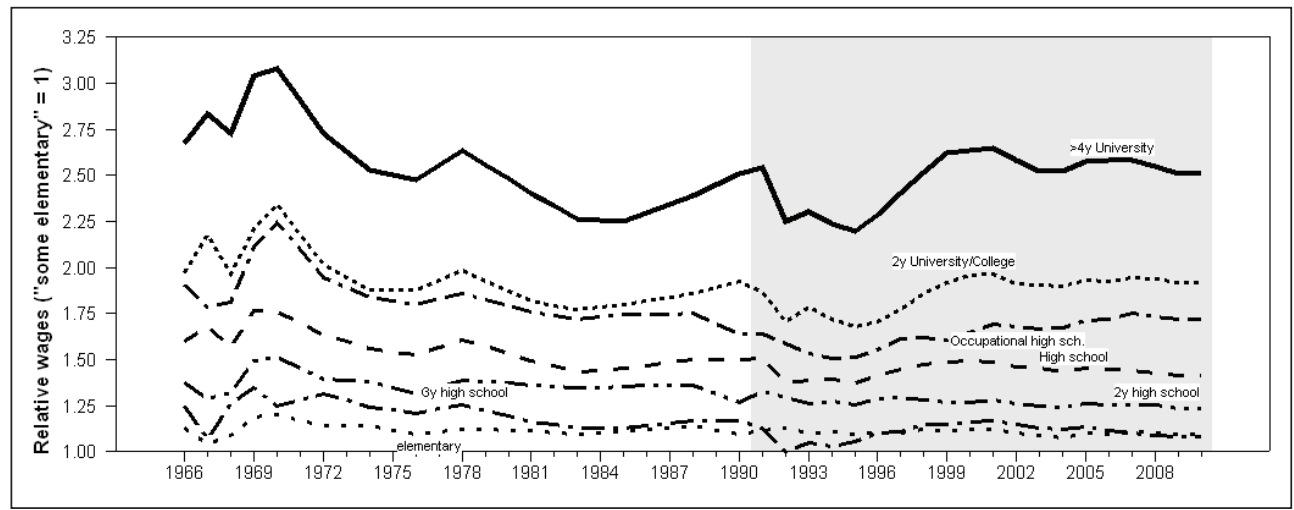


All the data were acquired from official statistics (SGH, 1971-1989, SLJH, 19912010, CBS, 2011b) which covered both series on annual basis after transition and biannual basis prior to $1990 .^{13}$

Figure 7: Human capital

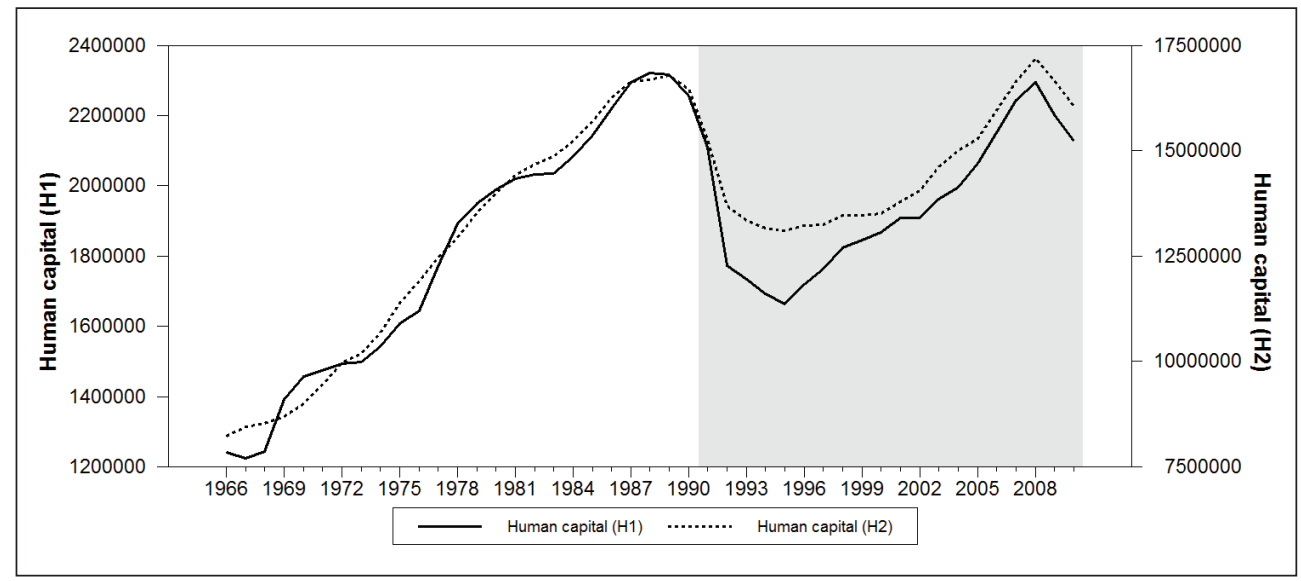

Source: Authors' calculation

Figure 5 and Figure 6 show data for educational attainments and relative wages between them and Figure 7 shows two estimated series for human capital.

\subsection{The growth accounting analysis}

The growth accounting methodology has resulted with 18 different estimates of TFP share in the growth rate of GDP. Figures A1, A2 and A3 in the Appendix show average growth rates for the four periods of interest.

Figure A1 shows the entire 1952-2010 sample due to the fact that data for physical capital and employment are available during the entire period. Nevertheless, sample for the 1968-2010 period is more representative on two accounts. First, it is comparable to the estimates made with human capital augmented labor that starts with 1968. Second, regardless of the methodology used for the estimation of initial level of capital, by late sixties estimates of physical capital collapse into two estimates - one for the geometric and another for the linear depreciation methodology (see Figure 7).

\footnotetext{
${ }^{13}$ All missing data points for the number of employees per educational attainment and average wages of employees in each group of educational attainment were linearly extrapolated. Having in mind that both series are very persistent we believe that linear extrapolation is the most efficient methodological approach to solve the issue of data gaps.
} 
Therefore, three subsamples are used in order to estimate impact of the transtion on the TFP share in GDP and to compare results between estimates with and without human capital. Subsample 1968-1989 represents pretransition time, subsample 1995-2010 represents post-war transition average, and 1990-2010 represents transition average including homeland war period (1990-1995).

Figures A1, A2 and A3 in the Appendix quite clearly show that average share of TFP is much higher after 1990 compared to pre 1990 and total sample. When it comes to robustness of the result, all the averages calculated using linear perpetual inventory method indicate strong increase in TFP share after transition period. Linear PIM with raw labor and H2 human capital estimate indicate that TFP share doubled or even tripled, while estimate with H1 human capital implies modest increase in TFP share.

Geometric perpetual inventory method resulted with increase of TFP's share after transtion, although the relative size of increase is smaller compared to linear PIM method, and estimate with $\mathrm{H} 1$ method results with modest increase in TFP share. In total, regardless of the PIM depreciation method and estimate of initial capital, average share of TFP strongly increased in 15 out of 18 estimates. In the case of three estimates with geometric PIM and H1 human capital, there is no increase in share of TFP in GDP growth. ${ }^{14}$

Figure A4 in the Appendix shows 18 estimates of TFP series (base index 1967=1). It is obvious that regardless of the initial capital level or depreciation methodology used, all estimates converged to roughly four, or even three different levels of TFP at the end of sample.

The group with the highest level of TFP at the end of sample has three estimates with linear PIM and raw labor. This result is straightforward. Linear depreciation results in a smaller growth rate of physical capital compared to geometric depreciation (Figure 7) and raw labor implies that all improvements in quality of labor (human capital) will end up in Solow residual. (Jorgenson and Griliches 1967) On the other hand, smallest TFP is estimated using geometric PIM and human capital adjusted labor. All six estimates with human capital and geometric PIM converged at the end of sample regardless of the methodology used to estimate human capital ( $\mathrm{H} 1 \mathrm{or} \mathrm{H} 2)$. And finally, group in between consists of nine estimates of TFP that have converged at the end of sample, although it is possible to divide this group of estimates into six estimates using linear PIM and human capital and three estimates with raw labor and geometric PIM.

\footnotetext{
$\overline{{ }^{14} \text { Figures A2a, A2c }}$ and A2e are outliers in terms of TFP increase and in terms of negative contribution of human capital to GDP.
} 
Obviously geometric PIM decreases TFP growth rates (higher growth rates of physical capital) as much as quality adjustment of labor (higher growth rate of human capital compared to raw labor) resulting in convergence of all TFP estimates that use either geometric PIM or quality adjusted labor. Estimates with linear PIM and raw labor have highest TFP growth rates, and estimates with both geometric PIM and quality adjusted labor have the smallest growth rates of TFP.

Figures A5 and A6 in the Appendix represent 18 estimates of shares of TFP growth rates in GDP growth rates and 18 estimates of TFP growth rates respectively. Structural break tests are performed on both series.

\subsection{Analysis of structural breaks}

In Andrews and Ploberger (1994) structural break test, only in 6 out of 18 TFP growth rate series resulted with significant structural break. In general, TFP estimates based on geometric PIM method resulted with much higher significance levels compared to linear PIM method estimates (Table A1 in the Appendix). Although, the majority of estimates was insignificant, it is interesting to highlight the fact that all estimates indicated year 1993 as a break point. ${ }^{15}$

Bai and Perron (2003a) test was performed in two steps. First, we have used $\operatorname{supF}_{T}(k ; q)$ and $\sup _{T}(\ell \mid \ell+1)$ test in order to endogenously estimate the number of breaks in a data series. Andrews and Ploberger (1994) test assumes only one break, while Bai and Perron (2003a) tests endogenously determine number of breaks in data.

Table A2 in the Appendix shows RSS, BIC, LWZ, $\sup _{T}(k ; q)$ and $\sup _{T}(\ell \mid \ell+1)$ statistics for $0,1,2$ and 3 structural breaks in each estimated TFP growth rate series. Following Bai and Perron (2003a) application technique, we used $\sup _{T}(\ell \mid \ell+1)$ test in order to find number of breaks that minimize equation 20 . We have used trimming $\varepsilon=0.2$ and critical values by Bai and Perron (2003b).

Results suggest that null hypothesis of $\ell$ number of breaks cannot be rejected at $\ell=2$ for a majority of TFP growth rate estimates. Only three estimates (linear PIM and $\mathrm{H} 1$ human capital) did not indicate breaks in $\operatorname{supF}_{T}(\ell \mid \ell+1)$ test, but on the other hand $\sup _{T}(k ; q)$ test implied two breaks at $5 \%$ significance level. Also, two estimates based on $\mathrm{H} 2$ human capital and linear PIM imply existence of only one break in $\sup _{T}(\ell \mid \ell+1)$ test with quite ambiguous results for $\sup F_{T}(k ; q)$ (Table A2 in the Appendix). ${ }^{16}$

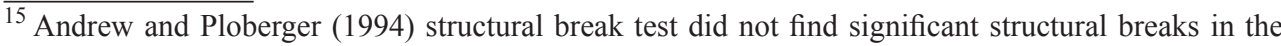
series for TFP growth rate share in GDP growth rate. The data is available from authors upon request.

${ }^{16}$ Bai Perron (2003) test estimated zero breaks in data for the TFP growth rate share in GDP growth rate. The data is available from authors upon request.
} 
We have proceeded with the estimation of two break points using Bai and Perron (2003a) test for all estimated TFP growth rate series. Table A3 in the Appendix shows the results of the test. For all 18 TFP growth rate series, Bai and Perron (2003a) test estimated first break in 1979 and second break in 1993.

Compared to Andrews and Ploberger (1994), Bai and Perron (2003a) test estimated additional break for most of the series and provided additional evidence that break in TFP growth rate occurred in 1993. Figure 1 shows the GDP level during the period and it is obvious that first estimated break corresponds to the beginning of the period of GDP stagnation during eighties and second break in 1993 represents turning point for GDP growth during the transition process.

When it comes to $95 \%$ significance band for estimated breaks it should be noted that bands are quite wide, covering sometimes more than a decade as a consequence of a short data sample. On the other hand, exactly the same break years are indicated in all 18 estimates, which might be interpreted as a sign of robustness.

Estimated average growth rates of TFP during three regimes are even more interesting. Prior to 1979, average growth rate of TFP in Croatia was positive between 0.7 and $1.6 \%$ depending on a TFP estimate. During the political turmoil in former-Yugoslavia between 1979 and 1993, average TFP growth rate was negative between -2.3 and $-3.6 \%$. After transition started, TFP growth rate became positive again ranging from 2.2 to $2.8 \%$ depending on the TFP estimate. ${ }^{17}$

\section{Results and discussion}

The results of the analysis have provided quite strong evidence that transition had profound effect on TFP growth rates, but insignificant effect on share of TFP in GDP. Namely, structural break tests have found strong evidence of two structural breaks in TFP growth rates - in 1979 and 1993 - and zero significant structural breaks in the share of TFP growth rate in GDP growth rate. The analysis was conducted with 18 different estimates of TFP growth rate series for Croatia obtained by the growth accounting methodology and the results for both share of TFP in GDP and GDP growth rate series are quite robust.

The first break in 1979 is closely connected with overall slowdown of growth in the eighties. The second estimated break in 1993 is in line with results in other countries (Albania, Bulgaria, Romania, Slovenia) where rebound of TFP growth rates

\footnotetext{
${ }^{17}$ We are grateful for the comment of an anonymous reviewer who pointed out that Bai Perron's test results that we have obtained could not be used as an evidence that post 1993 average growth rates of TFP are significantly higher compared to pre 1979 TFP growth rates. Although the average TFP growth rates are higher during transition compared to pre 1979 period, Bai Perron test did not test for structural break between first and third period. We leave this issue for future research to address.
} 
after an average of three years from transition has been identified. (Kaser, 2005, Iradian, 2007, Macours and Swinnen, 2000) In other words, transition reforms have changed the trend in TFP growth rates from negative to positive in Croatia after few initial years of transition as well. Obviously, during the initial years, removal of central planner produces negative TFP shock and it takes some time for reallocation of resources to happen and for macroeconomic stability to be achieved in order to compensate for the initial shock. Beyond that, it should be highlighted that Croatia experienced homeland war in addition to transition with majority of war destruction concentrated during 1991-1992 period. Second wave of privatisation ("pretvorba") happened during the 1992 and inflation was stabilised in the October of 1993. It is reasonable to assume that the constalation of all these events contributed to the recovery of the posttransition economy. After all these events, first positive growth rate of GDP was registered in 1994.

On the other hand, even though growth accounting analysis shows that average share of TFP is on average higher after 1990 compared to pre 1990 and total sample, structural break testing showed that higher post-transitional TFP growth rates did not affect the share of TFP growth in GDP growth. This can be interpreted as a consequence of similar effects of transition on other growth factors. If the impact of transition break in 1993 was similar on TFP, physical and human capital and labor, relative importance of growth factors should not change in a significant way. This finding implies that something idiosyncratic happened in the transition process in Croatia which significantly lessened the role of TFP and efficiency in the period that followed compared to what was expected. In other words, the way in which reforms were implemented and the way in which economic policy was conducted after that did not emphasise the relative role of total factor productivity compared to remaining growth factors.

Methodological choice of Bai-Perron (2003a) test has proved to be useful due to the fact that obviously in transition countries we can not expect a break in 1973/74 as it is exogenously assumed in the mainstream literature. Stagnation of the eighties and transitional slump at the beginning of the nineties have resulted with peculiar periodization of TFP behavior in transition countries, including Croatia.

When it comes to measurement sensitivity, analysis has shown that conclusions are quite robust to initial capital stock levels and human capital measures. As far as geometric versus linear perpetual inventory method is concerned, the results have indicated smaller level of robustness in the case of $\mathrm{H} 2$ augmented labor combined with linear depreciation technique. 


\section{Conclusion}

The results of the analysis have shown that transition had a positive effect on TFP growth rates, but insignificant effect on share of TFP in GDP growth. Given that the results have proven very robust, the hypothesis of the paper that transition had a positive impact on both the growth rate of TFP and its share in the GDP growth is thus only partialy proved. The results regarding positive effect of transition on TFP growth rates and the 1993 structural break are consistent with findings in other transition countries. However, the absence of statisticaly significant effect of transition on the share of TFP in GDP growth rate was unexpected and suggests a peculiarity in Croatian transition process that opens a space for further research. This study thus contributes to the economic science by filling the gap in the existing empirical literature on the transition process by providing robust estimates of the impact of transition on TFP in Croatia. Regarding limitations of this study, the fact that the entire analysis is based on previously published estimates of GDP for the pre-1990 period asks for additional explanation. Inclusion of pre-1990 estimated data for GDP have enabled us to estimate impact of transition on TFP growth rate. Official GDP numbers for pretransitional period do not exist and the only way to proceed with this line of research was to use GDP estimates. This presents unavoidable limitation of the study. However, additional advantage of usage of pre-1990 estimates is the fact that such a long run data has enabled us to construct physical capital series robust to the choice of initial level of capital during 1968-2010 which represents an additional contribution of this paper. Other studies on Croatian TFP that rely on official GDP data do not have problem with pre-transitional data, but on the other hand physical capital estimates in so small samples are extremely sensitive to the choice of methodology for the estimation of the initial level of capital. Potential avenues for the future research should be directed into the structure of transition reforms as well as comparative studies of transition reforms and general charateristics of countries involved in restructuring. Additionaly, it might be possible to get additional insights in peculiraties with two sectors growth accounting model. Identification of factors of indiosyncrasies of Croatian transition is of the outmost importance for the long run sustainability of the economy. In terms of the implications for the economic policy, our results imply that the transition had possitive impact on growth of the economy, but the structural quality of that growth did not significantly change compared to the previous period. In other words, structural reforms in the early 90 -ies did not move the economic structure in the direction that was theoretically expected in order to produce sustainable long run growth of the economy. In order to alleviate such a serious problem with the sustainability of the growth of Croatian economy it is of outmost importance to forge reform proposals that will prioritise relative importance of total factor productivity having in mind institutional order, political culture, legacies, and other peculiarities of the Croatian economy. 


\section{References}

Abramovitz, M. (1956) "Resource and Output Trends in the United States Since 1870", American Economic Review, Vol. 46, No. 2, pp. 5-23.

Ahmed, S., Ghani, E. (2007) South Asia: Growth and Regional Integration, Delhi: Macmillan India.

Akdede, S.H. (2001) Economic Liberalization, Markups, and Total Factor Productivity Growth in Turkey's Manufacturing Industries, Aydin: Adnan Menderes University.

Andrews, W. K. D., Ploberger, W. (1994) "Optimal Tests when a Nuisance Parameter is Present only Under the Alternative”, Econometrica, Vol. 62, No. 6, pp. 13831414, doi: 10.2307/2951753.

Bah, E. H. M., Brada, J. C. (2009) "Total factor productivity growth, structural change and convergence in the new members of the European Union", Comparative Economic Studies, Vol. 51, No. 4, pp. 421-446, doi: 10.1057/ ces.2009.8.

Bai, J., Perron, P. (1998) "Estimating and Testing Linear Models with Multiple Structural Changes", Econometrica, Vol. 66, No. 1, pp. 47-78, doi: $10.2307 / 2998540$.

(2003a) "Computation and Analysis of Multiple Structural Change Model", Journal of Applied Econometrics, Vol. 18, pp. 1-22, doi: http://dx.doi. org/10.1002/jae.659.

--------- (2003b) "Critical Values for Multiple Structural Change test", The Econometrics Journal, Vol. 6, No. 1, pp. 72-78, doi: 10.1111/1368-423x.00102.

Barro, R. J. (1998) "Notes on Growth Accounting”, Journal of Economic Growth, Springer, Vol. 4, No. 2, pp. 119-137, doi: 10.3386/w6654.

Benhabib, J., Spiegel, M. M. (1992) "The Role of Human Capital and Political Instability in Economic Development", Working Papers 92-24, C.V. Starr Center for Applied Economics, New York University.

Burda, M. C., Severgnini, B. (2009) "TFP Growth in Old and New Europe" Comparative Economic Studies, Palgrave Macmillan, Vol. 51, No. 4, pp. 447466, doi: 10.1057/ces.2009.19.

--------- (2014) "Solow Residuals without Capital Stock", Journal of Development Economics, Vol. 109, pp. 154-171, doi: 10.1016/j.jdeveco.2014.03.007.

Campos, N. F., Coricelli, A. (2002) "Growth in transition: what we know, what we don't, and what we should", Journal of economic literature, Vol. 40, No. 3, pp. 793-836, doi: 10.1257/002205102760273797.

CBS (1999) Statistička izvješća, 1090/1999. Zagreb: Croatian Bureau of Statistics. (2001) Statistička izvješća, 1147/2001, Zagreb: Croatian Bureau of Statistics. 
- (2009) National accounts - Revision of Annual Gross Domestic Product,

1995-2005, No. 12.1.3., Zagreb: Croatian Bureau of Statistics.

- (2010) National accounts - Revision of Annual Gross Domestic Product,

1995-2007, No. 12.1.5. Zagreb: Croatian Bureau of Statistics.

(2011a) National accounts - First Release Quarterly Gross Domestic

Product Estimate, No. 12.1.1/3. Zagreb: Croatian Bureau of Statistics.

(2011b) Employment and Wages in 2010, 1449/2011, Zagreb: Croatian

Bureau of Statistics.

Chessa, A. G., Schouwstra, M. C. (2005) "Total Factor Productivity and the

Mongolian Transition”, Tinbergen Institute Discussion Papers, No. 05-087/2,

Amsterdam: Tinbergen Institute.

Christensen, R. L., Cummings, D., Jorgenson, D. (1980) "Economic Growth, 1947-

73, an International Comparison". In Kendrick, J. W., Vaccara, B. N. eds., New

Developments in Productivity Measurement, Chicago: University of Chicago

Press, pp. 595-698.

Crafts, N. F. R. (1996) "The first Industrial Revolution: A Guided Tour for Growth

Economists", The American Economic Review, Vol. 86, No. 2, pp. 197-201.

de Vries, G. et al. (2012) "Deconstructing the BRICs: Structural Transformation and Aggregate Productivity Growth", Journal of Comparative Economics, Vol. 40, No. 2, pp. 211-227, doi: 10.2139/ssrn. 1998072.

Ding, S., Knight, J. (2009) "Can the Augmented Solow Model Explain China's Remarkable Economic Growth? A Cross-Country Panel Data Analysis", Journal of Comparative Economics, Elsevier, Vol. 37, No. 3, pp. 432-452, doi: 10.1016/j.jce.2009.04.006.

Družić, I. (2006) A Journey through Transition Time: With Special Reference to Croatia. Zagreb: Political Culture Publishing \& Research Institute.

Družić, I., Tica, J. (2002) "Dinamika i kontroverze gospodarskog razvitka Hrvatske". In Družić, I. ed., Znanstveni skup Stabilizacija - participacija - razvoj: povodom 80. obljetnice rođenja akademika Jakova Sirotkovića, profesora emeritusa: zbornik radova, Zagreb: Ekonomski fakultet, Sveučilište u Zagrebu, pp. 107-126.

Easterly, W., Levine, R. (2001) "It's Not Factor Accumulation: Stylized Facts and Growth Models", Working Paper No. 164, Central Bank of Chile, doi: 10.2139/ ssrn.269108.

Frankel, J. A., Romer, D. (1999) “Does Trade Cause Growth?", American Economic Review, American Economic Association, Vol. 89, No. 3, pp. 379-399, doi: 10.1257/aer.89.3.379.

Ganev, K. (2005a) "Can Educational Attainment Explain Total Factor Productivity? Growth Accounting Evidence from Seven Transition Countries for the Period 1991-2000" Journal of World Economic Review, Vol. 2, No. 1, pp. 1-23, doi: 10.2139/ssrn.2025900. 
(2005b) "Measuring Total Factor Productivity: Growth Accounting for Bulgaria", Bulgarian National Bank Discussion Paper, No. 48/2005. doi: 10.2139/ssrn.2025902.

Griliches, Z. (1988) "Productivity Puzzles and R\&D: Another Nonexplanation", Journal of Economic Perspectives, Vol. 2, No. 4, pp. 9-21, doi: 10.1257/ jep.2.4.9.

Hall, R. E., Jones, C.I. (1999) "Why do some countries produce so much more output per worker than others?", The quarterly journal of economics, Vol. 114, No. 1, pp. 83-116, doi: 10.3386/w6564.

Harberger, A. (1978) "Perspectives on Capital and Technology in Less Developed Countries". In Artis, M. J., Nobay, A. R. eds., Contemporary Economic Analysis, London: Croom Helm.

Hulten, C. R. (2001) "Total Factor Productivity: A Short Biography". In Hulten, C. R., Dean, E. R., Harper, M. J. eds., New Developments in Productivity Analysis, Chicago: University of Chicago Press, doi: 10.7208/ chicago/9780226360645.003.0012.

Iradian, G. (2007) "Rapid Growth in Transition Economies: Growth Accounting Approach", IMF Working Papers 07/164, International Monetary Fund, doi: 10.5089/9781451867282.001.

Islam, N., Dai, E. (2009) "Alternative Estimates of TFP Growth in China: Evidence from Application of the Dual Approach". In Islam, N. ed., Resurgent China: Issues for the Future, UK: Palgrave Macmillan, doi: 10.1057/9780230234253_11.

Jorgenson, D.W., Fraumeni, B.M. (1989) "The Accumulation of Human and Non-human Capital, 1948-84". In Lipsey, R. E., Stone Tice, H. eds., The Measurement of Saving, Investment, and Wealth, Chicago: University of Chicago Press.

Jorgenson, D. W., Griliches, Z. (1967) "The Explanation of Productivity Change", Review of Economic Studies, Vol. 34, No. 99, pp. 249-280, doi: 10.2307/2296675.

Jorgenson, D. W., Yip, E. (2001) "Whatever Happened to Productivity Growth?". In Hulten, C. R., Dean, E. R., Harper, M. J. eds., New Developments in Productivity Analysis, Chicago: University of Chicago Press, doi: 10.7208/ chicago/9780226360645.003.0012.

Kaser, M. (2005) "Growth Accounting for Eight Eurasian Economies: Factors Differentiating Future Prospects from Soviet and Transition Experience". In Morozova, I. ed., Towards Social Stability and Democratic Governance in Central Eurasia: Challenges to Regional Security, Vol. 49, IOS Press.

Krishna, P., Mitra, D. (1998) "Trade Liberalization, Market Discipline, and Productivity Growth: New Evidence from India", Journal of Development Economics, Elsevier, Vol. 56, No. 2, pp. 447-462, doi: 10.1016/s03043878(98)00074-1. 
Krugman, P. (1994) "The Myth of Asia's Miracle" Foreign Affairs, Vol. 73, No. 6, pp. 62-78, doi: 10.2307/20046929.

Kyriacou, G. A. (1991) "Level and Growth Effects of Human Capital: A CrossCountry Study of the Convergence Hypothesis", Working Papers 91-26, C.V. Starr Center for Applied Economics, New York University.

Lipsey, R. G., Carlaw, K. I. (2004) "Total Factor Productivity and the Measurement of Technological Change", Canadian Journal of Economics Vol. 37, No. 4, pp. 1118-1150, doi: 10.1111/j.0008-4085.2004.00263.x.

Macours, K., Swinnen, J. F. M. (2000) "Causes of Output Decline in Economic Transition: The Case of Central and Eastern European Agriculture", Journal of Comparative Economics, Vol. 28, No. 1, pp. 172-206, doi: 10.1006/jcec.1999.1643. Mankiw, N. G., Romer, D., Weil, D. (1992) "A Contribution to the Empirics of Economic Growth", Quarterly Journal of Economics, Vol. 107, No. 2, pp. 407437, doi: 10.3386/w3541.

Moore, D., Vamvakidis, A. (2007) "Economic Growth in Croatia: Potential and Constraints", WP/07/198, IMF Working Paper, International Monetary Fund, doi: 10.5089/9781451867626.001.

Raguž, I. (2011) Analiza osjetljivosti utjecaja ljudskog kapitala na ekonomski rast Republike Hrvatske, unpublished master thesis, Faculty of Economics and Business, University of Zagreb.

Raguž, I. Družić, I., Tica, J. (2011) "Human Capital in Growth Accounting: The Case of Croatia", Journal of International Scientific Publications: Educational Alternatives, Vol. 9, pp. 185-198.

Roaf, M. J., Atoyan, R., Joshi, B., Krogulski, M. K. (2014) Regional Economic Issues--Special Report 25 Years of Transition: Post-Communist Europe and the $I M F$, International Monetary Fund.

SLJH (1991-2010) Statistical Yearbook of Croatia, Croatian Bureau of Statistics.

SGH (1971-1989) Statistički godišnjak SR Hrvatske, Republički zavod za statistiku SR Hrvatske.

SGJ (1982) Statistički godišnjak Jugoslavije, Savezni zavod za statistiku. (1989) Statistički godišnjak Jugoslavije, Savezni zavod za statistiku.

Solow, R. M. (1957) “Technical change and the aggregate production function”, The review of Economics and Statistics, Vol. 39, pp. 312-320, doi: 10.2307/1926047.

Swan, T. W. (1956). "Economic growth and capital accumulation", Economic record, Vol. 32, No. 2, pp. 334-361, doi: 10.1111/j.1475-4932.1956.tb00434.x.

Wong, S. T., Seng, B. S. S. (1997) "Total Factor Productivity Growth in Singapore: Methodology and Trends". In Capital Stock Conference, 10-14 March 1997, Canberra: OECD, Agenda Item VII. Available at: < https://www.oecd.org/std/ na/2666910.pdf> [Accessed: September 30, 2016] 
Wößmann, L. (2003) "Specifying Human Capital”, Journal of Economic Surveys, Vol. 17, No. 3, pp. 239-270, doi: 10.1111/1467-6419.00195.

Young, A. (1992) "A Tale of Two Cities: Factor Accumulation and Technical Change in Hong Kong and Singapore", NBER Chapters. In NBER Macroeconomics Annual 1992, Vol. 7, pp. 13-64, doi: 10.2307/3584993.

(1995) "The Tyranny of Numbers: Confronting the Statistical Realities of the East Asian Growth Experience", The Quarterly Journal of Economics, Vol. 110, No. 3, pp. 641-680, doi: 10.3386/w4680. 


\title{
Utjecaj tranzicije na ukupnu faktorsku produktivnost $\mathrm{u}$ Hrvatskoj ${ }^{1}$
}

\author{
Irena Raguž Krištić ${ }^{2}$, Ivo Družić $\dot{c}^{3}$, Josip Tica
}

\begin{abstract}
Sažetak
Cilj ovog rada je istražiti utjecaj tranzicije na ukupnu faktorsku produktivnost (TFP) u Hrvatskoj. Hipoteza našeg rada jest da je tranzicija imala pozitivan utjecaj na stopu rasta TFP-a i njegov udio u rastu BDP-a. Koristimo metodologiju računovodstva rasta za procjenu TFP-a i testove strukturnih prekida za procjenu ukupnog broja i mjesta strukturnog(ih) prekida u procijenjenim serijama TFP-a. Kako bismo ispitali robusnost naših rezultata kombiniramo razlicite skupove pretpostavki te dobivamo 18 različitih TFP serija. Temeljni rezultati rada upućuju na to da je tranzicija imala pozitivan učinak na stopu rasta TFP-a, ali nije imala statistički značajan utjecaj na relativu važnost (udio) TFP-a u BDP-u. Testovi strukturnih prekida su pokazali dvije statistički značajne lokacije prekida u podacima stopa rasta TFP-a. Prvi prekid 1979.godine usko je povezan s općim usporavanjem rasta, dok se druga lokacija prekida 1993.godine može pripisati tranzicijskim reformama. Procjenjene lokacije strukturnih prekida su robusne za svih 18 procjenjenih TFP serija. Osnovni zaključak ovog istraživanja je da su tranzicijske reforme uspjele potaknuti rast gospodarstva u cjelini uključujući $i$ TFP-a, ali relativna važnost TFP-a vis a vis drugih faktora rasta kao što su ljudski ili fizički kapital nije se značajno promijenila.
\end{abstract}

Ključne riječi: ukupna faktorska produktivnost, tranzicija, računovodstvo rasta, strukturni prekidi

JEL klasifikacija: O30, O47, O52

1 Ovaj rad financirala je Hrvatska zaklada za znanost, broj projekta 7031. Autori izjavljuju da nemaju drugih relevantnih ili materijalnih financijskih interesa koji se odnose na istraživanja opisana u ovom radu.

Zahvale: Želimo se zahvaliti anonimnim recenzentima na korisnim komentarima. Također, zahvaljujemo sudionicima na 87. Međunarodnom susretu udruženja Western Economic Association u San Franciscu, Kalifornija, za korisne komentare, a posebno Julianu Neiri i Dan Bogartomu.

2 Docentica, Ekonomski fakultet Zagreb, Trg J. F. Kennedyja 6, 10000 Zagreb, Hrvatska. Znanstveni interes: makroekonomija, ekonomski rast, ekonomika okoliša, hrvatsko gospodarstvo.Tel.: +38512383144.Fax:+38512383333.E-mail: iraguzkristic@efzg.hr. Osobna web stranica: www.efzg.hr/iraguz (autorica za korespodenciju).

3 Redoviti profesor, Ekonomski fakultet Zagreb, Trg J. F. Kennedyja 6, 10000 Zagreb, Hrvatska. Znanstveni interes: gospodarstvo Hrvatske, makroekonomija, strukturne promjene, tranzicija, ekonomski rast. Tel.: +3851238 3142. Fax: +3851238 3333. E-mail: idruzic@efzg.hr. Osobna web stranica: www.efzg.hr/idruzic.

4 Redoviti profesor, Ekonomski fakultet Zagreb, Trg J. F. Kennedyja 6, 10000 Zagreb, Hrvatska. Znanstveni interes: makroekonomija, gospodarstvo Hrvatske, urbana ekonomika, ekonomika tečaja. Tel.: +3851238 3162.Fax: +3851238 3333. E-mail: jtica@efzg.hr. Osobna web stranica: www.efzg.hr/jtica. 


\section{Appendices}



Irena Raguž Krištić, Ivo Družić, Josip Tica •Impact of the transition on the total factor... Zb. rad. Ekon. fak. Rij. • 2016 • vol. $34 \cdot$ no. $2 \cdot 271-308$

Figure A1: Growth accounting with raw labor
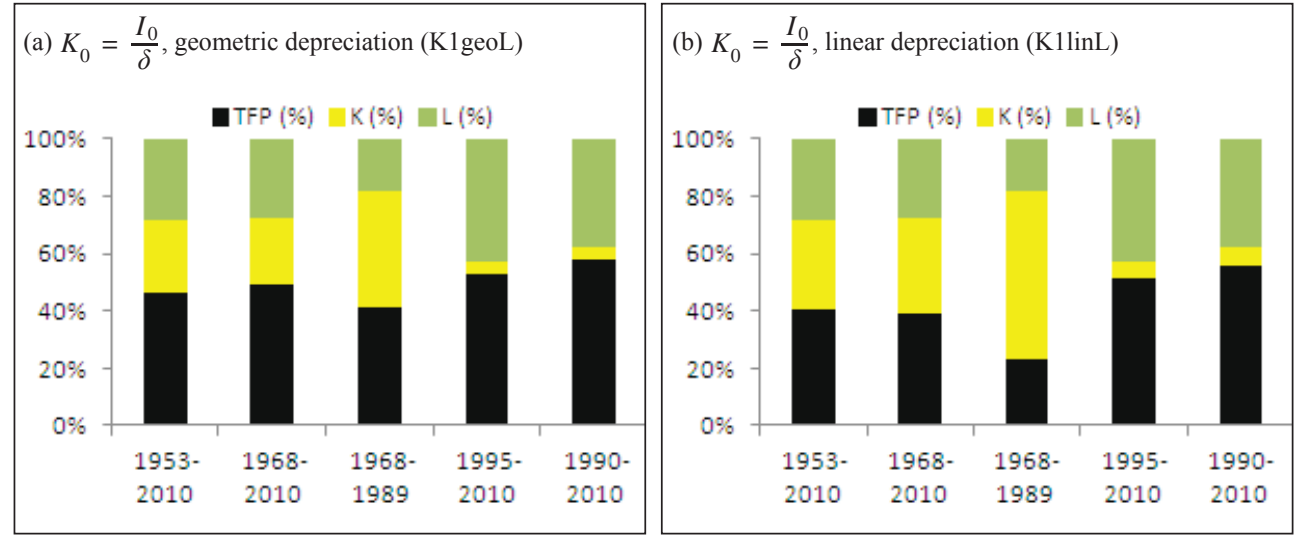

(c) $K_{0}=\frac{Y_{0} * \operatorname{avg}(I / Y)}{\operatorname{avg}\left(g_{Y}\right)+\delta}$, geometric depreciation $(\mathrm{K} 2$ geoL)

(d) $K_{0}=\frac{Y_{0} * a v g(I / Y)}{\operatorname{avg}\left(g_{Y}\right)+\delta}$, linear depreciation $(\mathrm{K} 2 \operatorname{linL})$
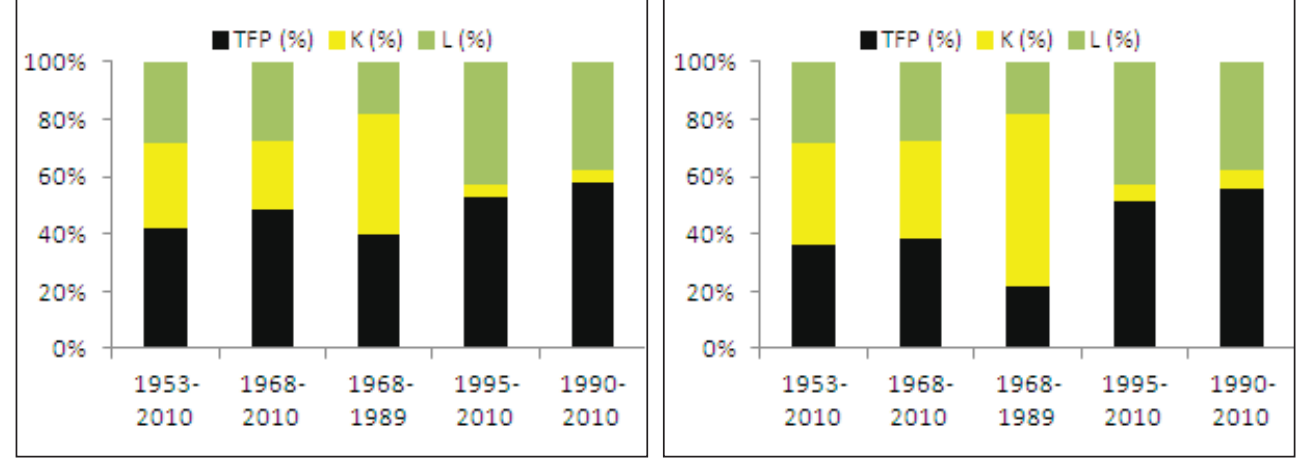

(e) $K_{0}=\frac{I_{0}}{\operatorname{avg}\left(g_{I}\right)+\delta}$, geometric depreciation $(\mathrm{K} 3$ geoL $)$

(f) $K_{0}=\frac{I_{0}}{\operatorname{avg}\left(g_{I}\right)+\delta}$, linear depreciation $(\mathrm{K} 3 \operatorname{linL})$
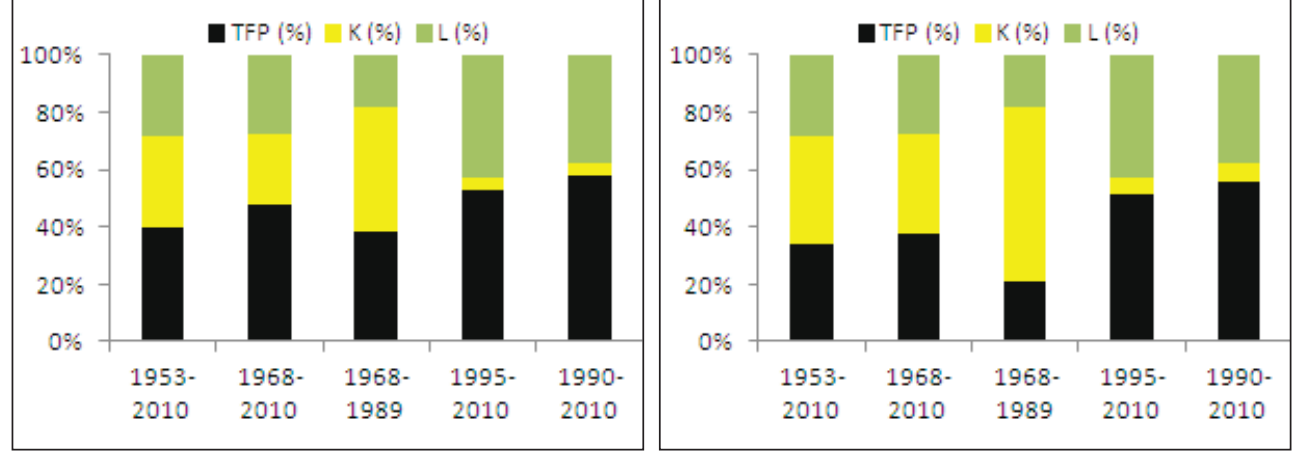

Source: Authors' calculation 
Figure A2: Growth accounting with human capital (relative wages) adjusted labor
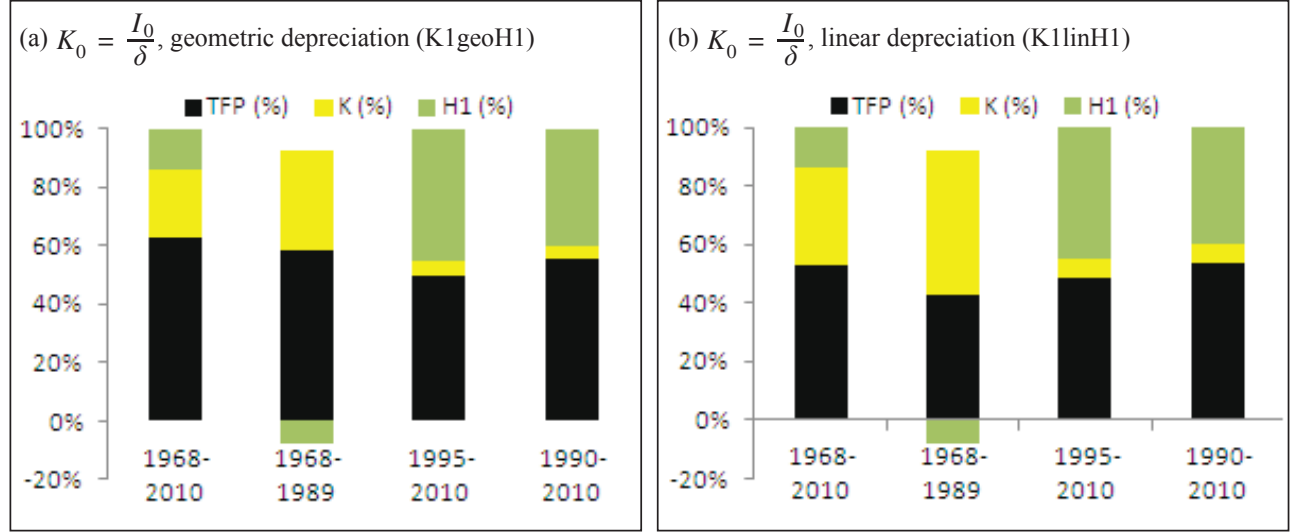

(c) $K_{0}=\frac{Y_{0} * \operatorname{avg}(I / Y)}{\operatorname{avg}\left(g_{Y}\right)+\delta}$, geometric depreciation $(\mathrm{K} 2 \mathrm{geoH} 1)$

(d) $K_{0}=\frac{Y_{0} * \operatorname{avg}(I / Y)}{\operatorname{avg}\left(g_{Y}\right)+\delta}$, linear depreciation $(\mathrm{K} 2 \operatorname{linH} 1)$
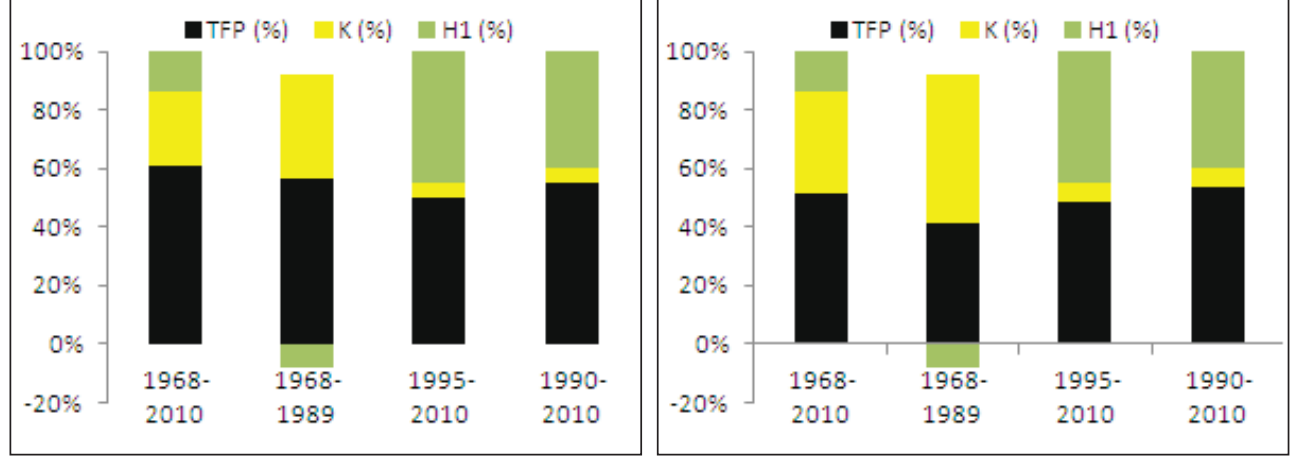

(e) $K_{0}=\frac{I_{0}}{\operatorname{avg}\left(g_{I}\right)+\delta}$, geometric depreciation $(\mathrm{K} 3$ geoH1)

(f) $K_{0}=\frac{I_{0}}{\operatorname{avg}\left(g_{I}\right)+\delta}$, linear depreciation $(\mathrm{K} 3 \operatorname{linH} 1)$
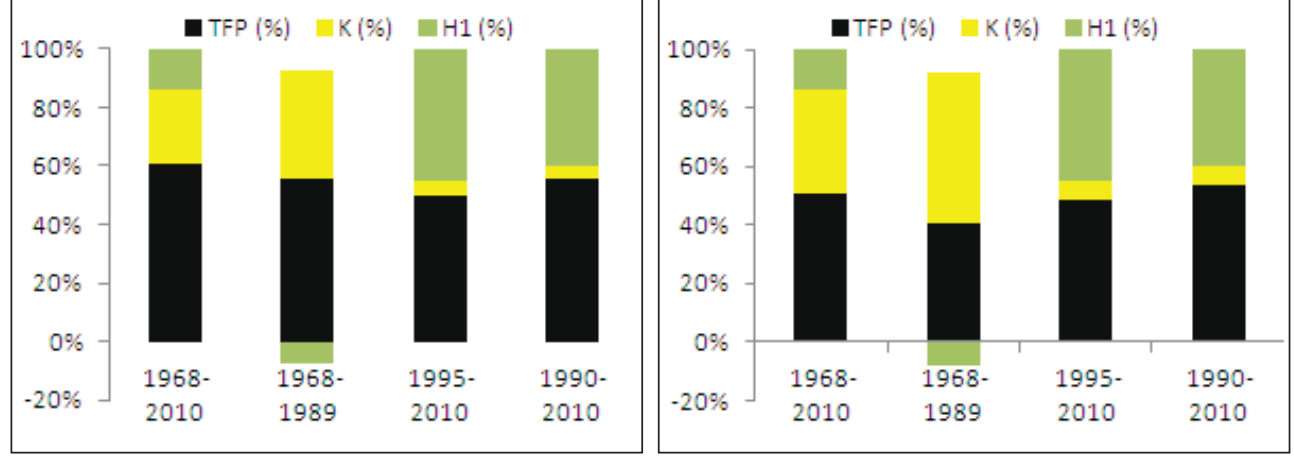

Source: Authors' calculation 
Irena Raguž Krištić, Ivo Družić, Josip Tica •Impact of the transition on the total factor...

Figure A3: Growth accounting with human capital (average years of schooling) adjusted labor
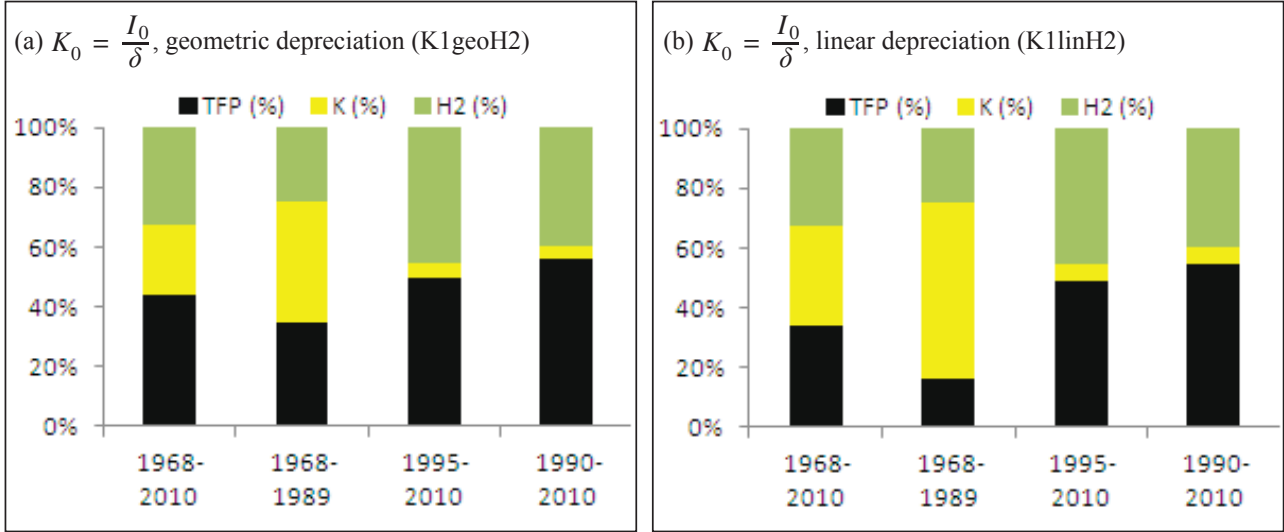

(c) $K_{0}=\frac{Y_{0} * \operatorname{avg}(I / Y)}{\operatorname{avg}\left(g_{Y}\right)+\delta}$, geometric depreciation $(\mathrm{K} 2 \mathrm{geoH} 2)$

(d) $K_{0}=\frac{Y_{0} * \operatorname{avg}(I / Y)}{\operatorname{avg}\left(g_{Y}\right)+\delta}$, linear depreciation (K2linH2)
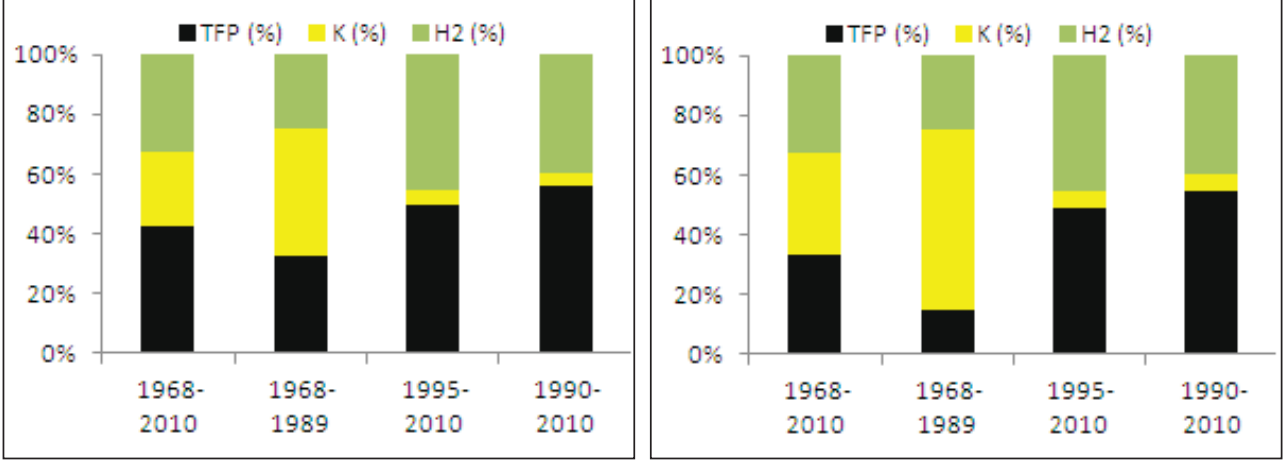

(e) $K_{0}=\frac{I_{0}}{\operatorname{avg}\left(g_{I}\right)+\delta}$, geometric depreciation $(\mathrm{K} 3$ geoH2)

(f) $K_{0}=\frac{I_{0}}{\operatorname{avg}\left(g_{I}\right)+\delta}$, linear depreciation $(\mathrm{K} 3 \operatorname{linH} 2)$
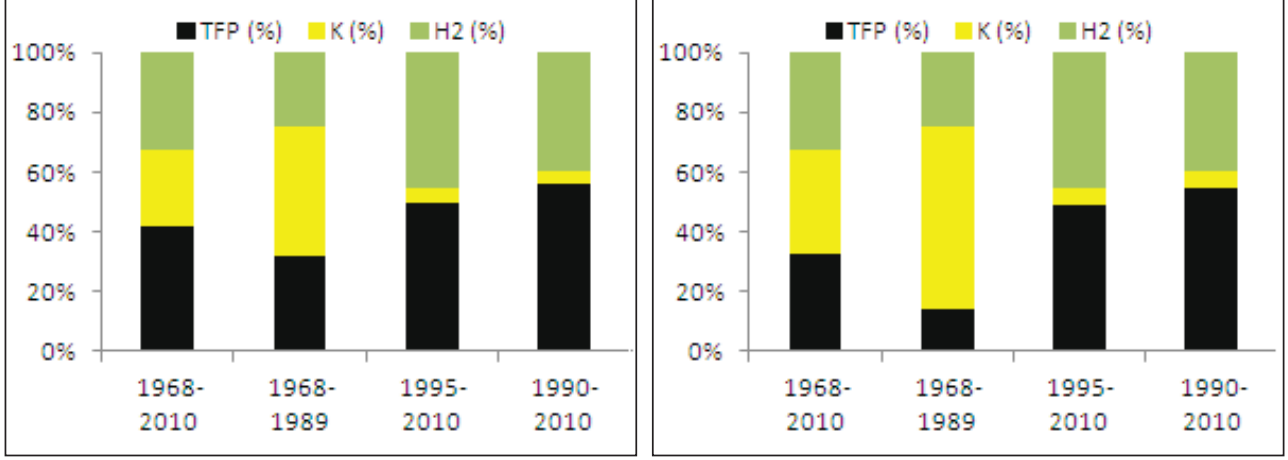

Source: Authors' calculation 
Figure A4: TFP 1967=1

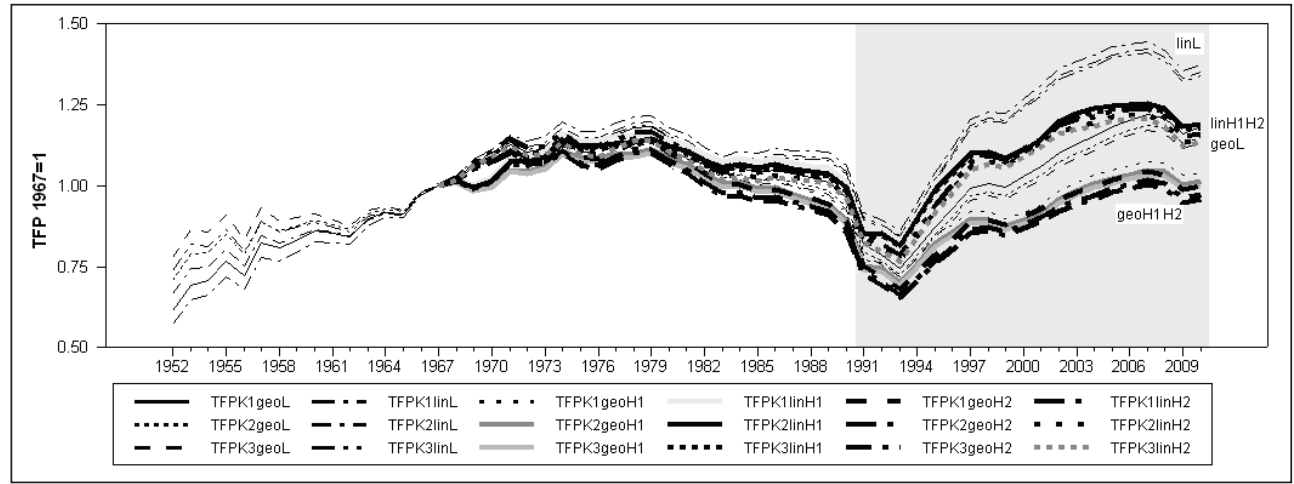

Source: Authors' calculation

Figure A5: Shares of TFP growth rates in GDP growth rates

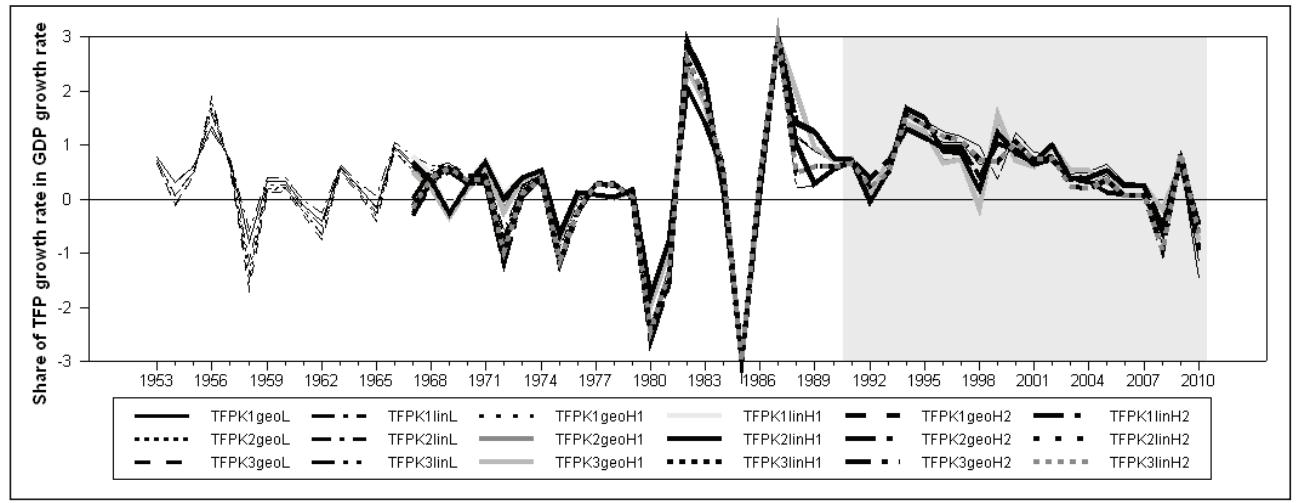

Source: Authors' calculation

Figure A6: TFP growth rates

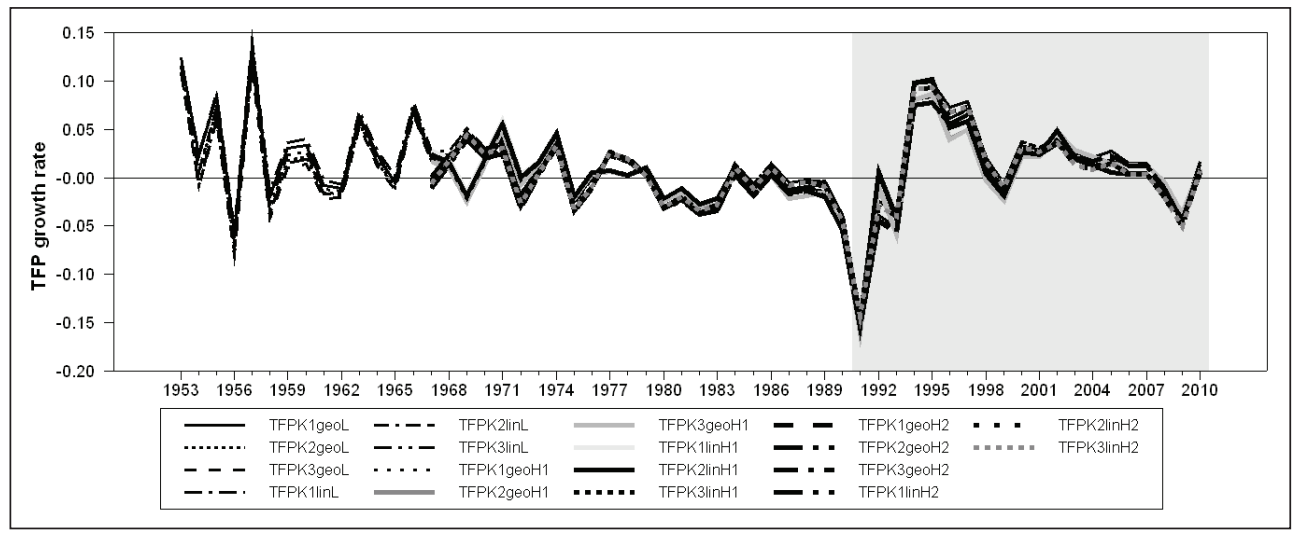

Source: Authors' calculation 
Irena Raguž Krištić, Ivo Družić, Josip Tica •Impact of the transition on the total factor...

Table A1: Andrews-Ploberger test - TFP growth rates

\begin{tabular}{|l|c|c|c|}
\hline \multicolumn{1}{|c|}{ Series } & $\begin{array}{c}\text { Break } \\
\text { Location }\end{array}$ & $\begin{array}{c}\text { AP } \\
\text { statistics }\end{array}$ & P-value \\
\hline K1geoL & 1993 & 1.702 & $0.076^{*}$ \\
\hline K2geoL & 1993 & 1.893 & $0.060^{*}$ \\
\hline K3geoL & 1993 & 1.994 & $0.053^{*}$ \\
\hline K1linL & 1993 & 1.001 & 0.196 \\
\hline K2linL & 1993 & 1.095 & 0.171 \\
\hline K3linL & 1993 & 1.146 & 0.159 \\
\hline K1geoH1 & 1993 & 1.202 & 0.147 \\
\hline K2geoH1 & 1993 & 1.341 & 0.122 \\
\hline K3geoH1 & 1993 & 1.418 & 0.110 \\
\hline K1linH1 & 1993 & 0.698 & 0.314 \\
\hline K2linH1 & 1993 & 0.748 & 0.290 \\
\hline K3linH1 & 1993 & 0.778 & 0.276 \\
\hline K1geoH2 & 1993 & 1.648 & $0.082^{*}$ \\
\hline K2geoH2 & 1993 & 1.834 & $0.065^{*}$ \\
\hline K3geoH2 & 1993 & 1.932 & $0.057^{*}$ \\
\hline K1linH2 & 1993 & 0.957 & 0.209 \\
\hline K2linH2 & 1993 & 1.053 & 0.182 \\
\hline K3linH2 & 1993 & 1.104 & 0.169 \\
\hline
\end{tabular}

Note: ${ }^{* * *},{ }^{* *}$, and ${ }^{*}$ represent significance at the $1 \%, 5 \%$, and $10 \%$ level respectively.

Source: Authors' calculation 
Table A2: Estimated number of breaks with Bai Perron break - TFP growth rates

\begin{tabular}{|c|c|c|c|c|c|c|}
\hline Series & $\begin{array}{l}\text { No. of } \\
\text { breaks }\end{array}$ & RSS & $\mathrm{BIC}$ & LWZ & $F_{T}(k ; q)$ & $F_{T}(\ell \mid \ell+1)$ \\
\hline \multirow[t]{4}{*}{ K1geoL } & 0 & 0.071 & -6.35 & -6.30 & & \\
\hline & 1 & 0.056 & -6.49 & -6.39 & $10.78^{* *}$ & $10.78^{* *}$ \\
\hline & 2 & 0.042 & $-6.62^{*}$ & $-6.42^{*}$ & $14.00^{* * *}$ & $14.10^{* * *}$ \\
\hline & 3 & 0.043 & -6.41 & -6.11 & $7.98^{* * *}$ & -1.56 \\
\hline \multirow[t]{4}{*}{ K2geoL } & 0 & 0.070 & -6.35 & -6.30 & & \\
\hline & 1 & 0.055 & -6.51 & -6.41 & $11.60^{* *}$ & $11.60^{* *}$ \\
\hline & 2 & 0.041 & $-6.62^{*}$ & $-6.43^{*}$ & $13.97^{* * * *}$ & $13.23^{* *}$ \\
\hline & 3 & 0.043 & -6.41 & -6.11 & $7.98^{* * *}$ & -1.53 \\
\hline \multirow[t]{4}{*}{ K3geoL } & 0 & 0.070 & -6.36 & -6.31 & & \\
\hline & 1 & 0.055 & -6.52 & -6.42 & $12.02^{* * * *}$ & $12.02^{* * *}$ \\
\hline & 2 & 0.041 & $-6.63^{*}$ & $-6.43^{*}$ & $13.96^{* * *}$ & $12.80^{* *}$ \\
\hline & 3 & 0.043 & -6.41 & -6.12 & $7.98^{* * *}$ & -1.51 \\
\hline \multirow[t]{4}{*}{ K1linL } & 0 & 0.072 & -6.34 & -6.29 & & \\
\hline & 1 & 0.061 & -6.41 & $-6.32^{*}$ & $7.53^{*}$ & $7.53^{*}$ \\
\hline & 2 & 0.049 & $-6.45^{*}$ & -6.26 & $9.05^{* *}$ & $9.27^{* * *}$ \\
\hline & 3 & 0.046 & -6.34 & -6.05 & $6.97^{* * *}$ & 2.54 \\
\hline \multirow[t]{4}{*}{ K2linL } & 0 & 0.071 & -6.35 & -6.30 & & \\
\hline & 1 & 0.059 & -6.44 & $-6.34^{*}$ & $8.07^{*}$ & $8.07^{*}$ \\
\hline & 2 & 0.049 & $-6.46^{*}$ & -6.26 & $8.99^{* *}$ & $8.63^{* * *}$ \\
\hline & 3 & 0.046 & -6.35 & -6.06 & $6.93^{* * *}$ & 2.56 \\
\hline \multirow[t]{4}{*}{ K3linL } & 0 & 0.070 & -6.35 & -6.30 & & \\
\hline & 1 & 0.059 & -6.45 & $-6.35^{*}$ & $8.34^{* *}$ & $8.34^{* *}$ \\
\hline & 2 & 0.049 & $-6.46^{*}$ & -6.27 & $8.95^{* *}$ & $8.32^{* * *}$ \\
\hline & 3 & 0.046 & -6.36 & -6.06 & $6.91^{* * *}$ & 2.57 \\
\hline \multirow[t]{4}{*}{ K1geoH1 } & 0 & 0.068 & -6.39 & -6.34 & & \\
\hline & 1 & 0.056 & -6.49 & $-6.39^{*}$ & $8.52^{* *}$ & $8.52^{* *}$ \\
\hline & 2 & 0.044 & $-6.56^{*}$ & -6.37 & $10.81^{* * *}$ & $11.22^{* *}$ \\
\hline & 3 & 0.044 & -6.39 & -6.09 & 6.86 & 0.03 \\
\hline \multirow[t]{4}{*}{ K2geoH1 } & 0 & 0.067 & -6.39 & -6.35 & & \\
\hline & 1 & 0.055 & -6.51 & $-6.41^{*}$ & $9.20^{* *}$ & $9.20^{* * *}$ \\
\hline & 2 & 0.044 & $-6.57^{*}$ & -6.37 & $10.74^{* * *}$ & $10.44^{* *}$ \\
\hline & 3 & 0.044 & -6.39 & -6.10 & $6.82^{* * *}$ & 0.03 \\
\hline \multirow[t]{4}{*}{ K3geoH1 } & 0 & 0.067 & -6.40 & -6.35 & & \\
\hline & 1 & 0.055 & -6.51 & $-6.42^{*}$ & $9.54^{* *}$ & $9.54^{* *}$ \\
\hline & 2 & 0.044 & $-6.57^{*}$ & -6.37 & $10.71^{* * * *}$ & $10.05^{* *}$ \\
\hline & 3 & 0.044 & -6.40 & -6.10 & $6.80^{* * * *}$ & 0.03 \\
\hline K1linH1 & 0 & 0.068 & -6.39 & $-6.34^{*}$ & & \\
\hline
\end{tabular}


Irena Raguž Krištić, Ivo Družić, Josip Tica • Impact of the transition on the total factor...

Zb. rad. Ekon. fak. Rij. • 2016 • vol. $34 \cdot$ no. $2 \cdot 271-308$

\begin{tabular}{|c|c|c|c|c|c|c|}
\hline Series & $\begin{array}{l}\text { No. of } \\
\text { breaks }\end{array}$ & RSS & $\mathrm{BIC}$ & LWZ & $F_{T}(k ; q)$ & $F_{T}(\ell \mid \ell+1)$ \\
\hline & 1 & 0.060 & $-6.43^{*}$ & -6.33 & 5.83 & 5.83 \\
\hline & 2 & 0.050 & -6.43 & -6.23 & $7.02^{* *}$ & 7.45 \\
\hline & 3 & 0.050 & -6.26 & -5.96 & $4.53^{*}$ & 0.18 \\
\hline \multirow[t]{4}{*}{$\mathrm{K} 2$ linH1 } & 0 & 0.068 & -6.39 & -6.35 & & \\
\hline & 1 & 0.059 & $-6.45^{*}$ & $-6.35^{*}$ & 6.26 & 6.26 \\
\hline & 2 & 0.050 & -6.43 & -6.24 & $6.91^{* *}$ & 6.85 \\
\hline & 3 & 0.050 & -6.27 & -5.97 & $4.46^{*}$ & 0.18 \\
\hline \multirow[t]{4}{*}{ K3linH1 } & 0 & 0.067 & -6.40 & -6.35 & & \\
\hline & 1 & 0.058 & $-6.45^{*}$ & $-6.36^{*}$ & 6.47 & 6.47 \\
\hline & 2 & 0.050 & -6.43 & -6.24 & $6.86^{* *}$ & 6.56 \\
\hline & 3 & 0.050 & -6.27 & -5.97 & $4.43^{*}$ & 0.18 \\
\hline \multirow[t]{4}{*}{ K1geoH2 } & 0 & 0.071 & -6.34 & -6.30 & & \\
\hline & 1 & 0.057 & -6.48 & -6.39 & $10.59^{\text {** }}$ & $10.59^{* *}$ \\
\hline & 2 & 0.043 & $-6.59^{*}$ & $-6.39^{*}$ & $13.00^{* * *}$ & $12.71^{\text {** }}$ \\
\hline & 3 & 0.045 & -6.37 & -6.08 & $7.42^{* * *}$ & -1.48 \\
\hline \multirow[t]{4}{*}{ K2geoH2 } & 0 & 0.071 & -6.35 & -6.30 & & \\
\hline & 1 & 0.056 & -6.50 & $-6.40^{*}$ & $11.38^{* *}$ & $11.38^{* *}$ \\
\hline & 2 & 0.043 & $-6.59^{*}$ & -6.39 & $12.96^{* * *}$ & $11.87^{* *}$ \\
\hline & 3 & 0.045 & -6.38 & -6.08 & $7.43^{\text {*** }}$ & -1.42 \\
\hline \multirow[t]{4}{*}{ K3geoH2 } & 0 & 0.071 & -6.35 & -6.30 & & \\
\hline & 1 & 0.055 & -6.51 & $-6.41^{*}$ & $11.78^{* *}$ & $11.78^{* * *}$ \\
\hline & 2 & 0.043 & $-6.59^{*}$ & -6.40 & $12.95^{* * *}$ & $11.46^{* *}$ \\
\hline & 3 & 0.044 & -6.38 & -6.08 & $7.44^{* * *}$ & -1.39 \\
\hline \multirow[t]{4}{*}{$\mathrm{K} 1 \operatorname{lin} \mathrm{H} 2$} & 0 & 0.071 & -6.34 & -6.29 & & \\
\hline & 1 & 0.061 & -6.42 & $-6.32^{*}$ & $7.45^{*}$ & $7.45^{*}$ \\
\hline & 2 & 0.050 & $-6.44^{*}$ & -6.24 & $8.51^{* *}$ & $8.42^{* * * *}$ \\
\hline & 3 & 0.047 & -6.32 & -6.02 & $6.37^{* *}$ & 2.06 \\
\hline \multirow[t]{4}{*}{$\mathrm{K} 2 \operatorname{lin} \mathrm{H} 2$} & 0 & 0.071 & -6.35 & -6.30 & & \\
\hline & 1 & 0.059 & -6.44 & $-6.34^{*}$ & $7.97^{*}$ & $7.97^{*}$ \\
\hline & 2 & 0.050 & $-6.44^{*}$ & -6.25 & $8.43^{\text {** }}$ & 7.79 \\
\hline & 3 & 0.047 & -6.32 & -6.02 & $6.32^{* *}$ & 2.07 \\
\hline \multirow[t]{4}{*}{$\mathrm{K} 3 \operatorname{lin} \mathrm{H} 2$} & 0 & 0.070 & -6.35 & -6.30 & & \\
\hline & 1 & 0.059 & $-6.44^{*}$ & $-6.35^{*}$ & $8.22^{\text {** }}$ & $8.22^{* *}$ \\
\hline & 2 & 0.050 & -6.44 & -6.25 & $8.39^{* *}$ & 7.49 \\
\hline & 3 & 0.047 & -6.32 & -6.03 & $6.30^{* *}$ & 2.08 \\
\hline
\end{tabular}

Note: For BIC and LWZ * represents minimum. For supF tests ${ }^{* * *},{ }^{* *}$, and ${ }^{*}$ represent significance at the $1 \%, 5 \%$, and $10 \%$ level respectively. SupF critical values are for $q=1, \varepsilon=0.2$ (Bai and Perron 2003b).

Source: Authors' calculation 
Irena Raguž Krištić, Ivo Družić, Josip Tica • Impact of the transition on the total factor... 308 Zb. rad. Ekon. fak. Rij. • 2016 • vol. $34 \cdot$ no. 2 • 271-308

Table A3: Estimated break locations with Bai Perron break test - TFP growth rates

\begin{tabular}{|c|c|c|c|c|c|c|}
\hline \multirow{2}{*}{ Series } & \multirow{2}{*}{$\begin{array}{l}\text { Break(s) } \\
\text { Location }\end{array}$} & \multicolumn{2}{|c|}{$95 \%$} & \multicolumn{3}{|c|}{ Constant } \\
\hline & & Lower & Upper & $\leq$ break1 & $\leq$ break2 & $>$ break2 \\
\hline \multirow[t]{2}{*}{ K1geoL } & 1979 & 1966 & 1980 & 0.015 & -0.032 & 0.028 \\
\hline & 1993 & 1986 & 2000 & & & \\
\hline \multirow[t]{2}{*}{ K2geoL } & 1979 & 1966 & 1980 & 0.013 & -0.032 & 0.028 \\
\hline & 1993 & 1986 & 2000 & & & \\
\hline \multirow[t]{2}{*}{ K3geoL } & 1979 & 1965 & 1980 & 0.012 & -0.032 & 0.028 \\
\hline & 1993 & 1986 & 2000 & & & \\
\hline \multirow[t]{2}{*}{ K1linL } & 1979 & 1965 & 1982 & 0.018 & -0.024 & 0.028 \\
\hline & 1993 & 1977 & 2000 & & & \\
\hline \multirow[t]{2}{*}{ K2linL } & 1979 & 1964 & 1981 & 0.016 & -0.024 & 0.028 \\
\hline & 1993 & 1977 & 2000 & & & \\
\hline \multirow[t]{2}{*}{ K3linL } & 1979 & 1964 & 1981 & 0.015 & -0.024 & 0.028 \\
\hline & 1993 & 1977 & 2000 & & & \\
\hline \multirow[t]{2}{*}{ K1geoH1 } & 1979 & 1967 & 1980 & 0.012 & -0.031 & 0.023 \\
\hline & 1993 & 1985 & 2000 & & & \\
\hline \multirow[t]{2}{*}{ K2geoH1 } & 1979 & 1966 & 1980 & 0.010 & -0.032 & 0.022 \\
\hline & 1993 & 1985 & 2000 & & & \\
\hline \multirow[t]{2}{*}{ K3geoH1 } & 1979 & 1965 & 1980 & 0.009 & -0.032 & 0.022 \\
\hline & 1993 & 1985 & 2000 & & & \\
\hline \multirow[t]{2}{*}{ K1linH1 } & 1979 & 1966 & 1981 & 0.014 & -0.023 & 0.023 \\
\hline & 1993 & 1975 & 2000 & & & \\
\hline \multirow[t]{2}{*}{ K2linH1 } & 1979 & 1965 & 1980 & 0.013 & -0.023 & 0.023 \\
\hline & 1993 & 1975 & 2000 & & & \\
\hline \multirow[t]{2}{*}{ K3linH1 } & 1979 & 1964 & 1980 & 0.012 & -0.023 & 0.023 \\
\hline & 1993 & 1975 & 2000 & & & \\
\hline \multirow[t]{2}{*}{ K1geoH2 } & 1979 & 1965 & 1980 & 0.010 & -0.035 & 0.023 \\
\hline & 1993 & 1986 & 2001 & & & \\
\hline \multirow[t]{2}{*}{ K2geoH2 } & 1979 & 1964 & 1980 & 0.008 & -0.036 & 0.023 \\
\hline & 1993 & 1986 & 2001 & & & \\
\hline \multirow[t]{2}{*}{ K3geoH2 } & 1979 & 1963 & 1980 & 0.007 & -0.036 & 0.023 \\
\hline & 1993 & 1986 & 2001 & & & \\
\hline \multirow[t]{2}{*}{ K1linH2 } & 1979 & 1963 & 1982 & 0.012 & -0.027 & 0.024 \\
\hline & 1993 & 1977 & 2001 & & & \\
\hline \multirow[t]{2}{*}{ K2linH2 } & 1979 & 1962 & 1981 & 0.011 & -0.027 & 0.024 \\
\hline & 1993 & 1977 & 2001 & & & \\
\hline \multirow[t]{2}{*}{ K3linH2 } & 1979 & 1961 & 1981 & 0.010 & -0.027 & 0.024 \\
\hline & 1993 & 1977 & 2001 & & & \\
\hline
\end{tabular}

Source: Authors' calculation 